\title{
NATIONAL TYPES: THE TRANSATLANTIC PUBLICATION AND RECEPTION OF CRANIA AMERICANA (1839)
}

\author{
James Poskett \\ University of Cambridge
}

\section{INTRODUCTION}

In February 1842, the Monthly review in London hailed the arrival of a new folio volume. Illustrated by "admirable plates, drawn from skulls", this "philosophic" work represented a "very valuable and curious contribution to the natural history of man". Significantly, the author was also identified as a "Transatlantic Professor". 1 This was a man capable of studying the New World without abandoning the traditions of the Old, a man capable of commissioning beautiful illustrations in Philadelphia which might be mistaken for those printed in Paris and, most impressively, a man capable of getting an American work of natural history taken seriously in Europe.

The folio under inspection was Samuel George Morton's Crania Americana (Figure 1). Morton had graduated with a medical degree from the University of Pennsylvania in 1820 and, supported financially by his work as a physician in Philadelphia, amassed a vast collection of human skulls. Many of these specimens arrived through his contacts at the Academy of Natural Sciences in the city. ${ }^{2}$ Published in Philadelphia in the winter of 1839 , Crania Americana featured seventy-eight lithographic plates of North and South American

\footnotetext{
The following text is an open-access copy of the original manuscript. For the typeset edition, please consult the History of Science website: $\underline{\text { http://www.shpltd.co.uk/hs.html }}$

1 “Crania Americana”, Monthly review, i (1842), 157-73, p. 158.

${ }^{2}$ Robert Bieder, Science encounters the Indian: 1820-1880 (Norman, 2003), p. 56.
} 
skulls, ranging from "Esqimaux" in the north to "Peruvians" in the south. In the accompanying text, printed on the same folio paper, Morton followed Johann Blumenbach in dividing man into five races before linking these races to skull configuration. By the $1850 \mathrm{~s}$, Morton was sufficiently acclaimed to be described as "the Founder of the American School of Ethnology" by Josiah Nott, author of Types of mankind. ${ }^{3}$

Historians today have largely followed this national narrative. Bruce Dain identifies Crania Americana as one of the "foundational texts of an American scientific movement". 4 Similarly, Ann Fabian, in her excellent study, describes Morton's work as "a distinctive American enquiry". ${ }^{5}$ However, as the Monthly review invites us to consider, these national accounts tend to disregard the transatlantic context in which Morton operated. ${ }^{6}$ Bringing together archival sources from both Britain and the United States for the first time, this paper resituates Crania Americana within the transatlantic world in which it was originally produced and read. ${ }^{7}$

\footnotetext{
${ }^{3}$ Josiah Nott, Types of mankind (Philadelphia, 1854), p. 87.

${ }^{4}$ Bruce Dain, A hideous monster of the mind: American race theory in the early republic (Boston, 2002), p. 197.

${ }^{5}$ Ann Fabian, Skull collectors: race, science, and America's unburied dead (Chicago, 2010), p. 1.

${ }^{6}$ On the move towards global histories of science, see Sujit Sivasundaram, "Sciences and the global: on methods, questions, and theory", Isis, ci (2010), 146-58. Fabian, op. cit. (ref. 5) is the most sophisticated history of Crania Americana within the context of the United States to date. Other helpful accounts include William Stanton, The leopard's spots: scientific attitudes towards race in America 1815-1860 (Chicago, 1960) and Stephen Gould, The mismeasure of man (New York, 1981).

${ }^{7}$ Morton's archival papers are housed in libraries ranging from the American Philosophical Society in Philadelphia to the National Library of Scotland in Edinburgh.
} 


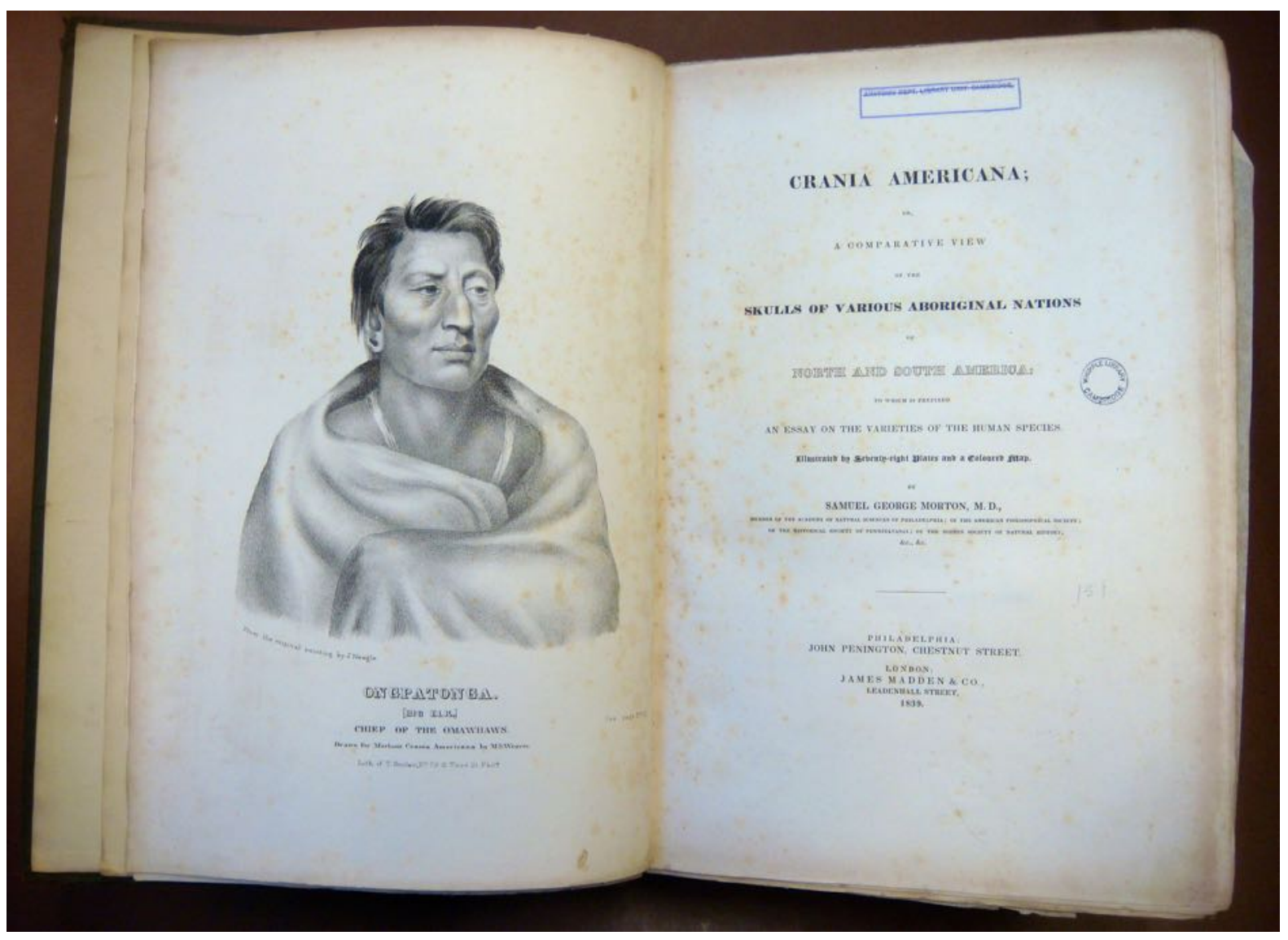

Figure 1: Frontispiece and title page, Crania Americana, Whipple Library, University of Cambridge.

In charting the publication and reception of Morton's work, this study contributes to two broader historiographies. Studies of science and the book are currently dominated by national frameworks. When the field was still developing, this national focus proved pragmatic. The initial aim was simply to show that books cannot be read outside of particular contexts. ${ }^{8}$ What's more, previous scholars are certainly not guilty of treating national contexts as homogeneous. James Secord himself points this out, urging us to consider the very real differences between Liverpool and London in his study of Robert Chambers's Vestiges of the natural history of creation. ${ }^{9}$ However, the difference between reading in Philadelphia, as

\footnotetext{
${ }^{8}$ Marina Frasca-Spada and Nicholas Jardine, "Introduction: books and the sciences", in Marina Frasca-Spada and Nicholas Jardine (eds), Books and the sciences in history (Cambridge, 2000), 1-12, p. 2.

${ }^{9}$ James Secord, Victorian sensation: the extraordinary publication, reception, and secret authorship of Vestiges of the natural history of creation (Chicago, 2000), p. 192.
} 
opposed to Liverpool, was not just a question of increased physical distance. There were distinct material, political and intellectual challenges faced by historical actors when operating transnationally: crates of books were lost at sea amidst the swells of an unforgiving Atlantic Ocean, whilst nationalist attitudes towards American science, particularly following the War of 1812, hampered any chance of a consistent reception across the Old World and the New. ${ }^{10}$ Thinking transnationally therefore allows us to resituates local contexts of publication and reception, not replace them.

Furthermore, whilst only one edition of Crania Americana was ever printed, the work nonetheless circulated in a variety of fragmentary forms. Copies of the prospectus, loose plates and reviews all criss-crossed the Atlantic in the months immediately before and after publication. The character of this two-way flow of traffic challenges conventional national histories of publication and reception. We cannot simply treat Crania Americana as a work produced in the United States and received in Europe. A range of actors on both sides of the Atlantic informed practices ranging from printing and publishing to advertising and reviewing. Literary, political and book historians have been quicker to recognize the significance of this transatlantic culture than historians of science, at least for the nineteenth century. ${ }^{11}$ Drawing on such work, this paper demonstrates how we might move forward with studies of science and the book.

\footnotetext{
${ }^{10}$ Barry Joyce, The shaping of American ethnography: the Wilkes exploring expedition 1838-1842 (Nebraska, 2001), p. 7 describes this as a period of "new nationalism".

${ }^{11}$ For literary studies, see John Barton, Jennifer Phegley and Kristin Huston (eds), Transatlantic sensations (Farnham, 2010). For transatlantic book history, see Michael Winship ,"The international trade in books", in Scott Casper, Jeffrey Groves, Stephen Nissenbaum, Michael Winship (eds), A history of the book in America: the industrial book (North Carolina, 2007), 148-57. In contrast, transatlantic histories of science are mostly confined to the early modern period, see James Delbourgo and Nicholas Dew (eds), Science and empire in the Atlantic world (New York, 2007). Aileen Fyfe, Steam-powered knowledge: William Chambers and the business of publishing 1820-1860 (Chicago, 2012) is a notable exception, although it deals with a very different kind of publication.
} 
By resituating Morton within a transatlantic context, this study also challenges existing histories of anthropology. The field is currently characterized by an asymmetrical attitude towards the production and communication of knowledge. ${ }^{12}$ Historians have no problem identifying the entangled transnational circuits on which nineteenth-century anthropologists relied for specimens. Indeed, Fabian's impressive reconstruction of Morton's skull collecting network is a case in point, taking us from Peru to Egypt. ${ }^{13}$ But when it comes to publication and reading, historians of anthropology have been unwilling to move beyond the confines of particular national traditions. A recent edited volume gives a sense of the current state of play. Henrika Kuklick's New history of anthropology features a section on "Major Traditions" with separate chapters dedicated to the disciplinary history of British, French, German and American anthropology..$^{14}$ Despite the wealth of research on men such as James Cowles Prichard and Morton, there has not been a single account which identifies the close intellectual and material ties between the making of American and British ethnography.

The sources uncovered in this study immediately alert us to the fallacy of treating Prichard and Morton as the founding fathers of independent national traditions. To take just one example, Prichard was the first to display Morton's cranial illustrations to a European audience. He did so at the 1839 British Association for the Advancement of Science meeting in Birmingham. Previous historians have recognized the significance of this meeting in the disciplinary history of British anthropology. ${ }^{15}$ However, these accounts entirely omit to mention the presence of Morton's lithographs. As this episode suggests, foundational

\footnotetext{
${ }^{12}$ For a critique of the divide between knowledge production and communication, see James Secord,

"Knowledge in transit", Isis, xcv (2004), 654-72.

${ }^{13}$ Fabian, op. cit. (ref. 5).

${ }^{14}$ Henrika Kuklick (ed.), New history of anthropology (Malden, 2007).

${ }^{15}$ Hannah Augstein, James Cowles Prichard's anthropology: remaking the science of man in early nineteenthcentury Britain (Atlanta, 1999), p. 145; Jack Morrell and Arnold Thackray, Gentlemen of science: early of the British association for the advancement of science (New York, 1982), pp. 283-86; Charles Withers, Geography and science in Britain 1831-1939 (Manchester, 2010), p. 168.
} 
moments in British and American anthropology were in fact bound together, both intellectually and materially.

Finally, Crania Americana is too often approached solely from within histories of ethnology or anthropology. ${ }^{16}$ However, for historical actors in the early 1840 s, the disciplinary position of Crania Americana was far from obvious. Only later in the nineteenth century was it consistently referred to as a work of "American ethnology". ${ }^{17}$ In contrast, between 1839 and 1842, readers and reviewers on both sides of the Atlantic strived to situate Morton's impressive tome within a range of emerging sciences of man. Following Prichard, many did read it as a work of ethnology. Further reviewers positioned Morton's work within traditions ranging from natural history to geography and medical physiology. Others also believed strongly that Crania Americana should be understood as a contribution to phrenology. It is this connection with phrenology which is most often glossed over by historians today. ${ }^{18}$ This is despite the fact that George Combe, the Edinburgh phrenologist and author of the best-selling Constitution of man, wrote a twenty-three page appendix for the work at Morton's request. At the time, Combe was an international celebrity, conducting a lecture tour of the United States. Today, historians often ask whether Morton took phrenology seriously. ${ }^{19}$ This is exactly the question nineteenth-century readers also struggled with: was Crania Americana a work of phrenology, or ethnology, or something else? At the time, these distinctions were far from clear. Beginning with the early arrival of Morton's loose lithographic plates in Birmingham, this paper demonstrates how debates over the

\footnotetext{
${ }^{16}$ For example, Thomas Glick, "The anthropology of race across the Darwinian revolution”, in Henrika Kuklick (ed.), New history of anthropology (Malden, 2007), 225-41, p. 225 and Joyce, op. cit. (ref. 10), p.19.

17 “American Ethnology”, American Review, ix (1854), 385-98. The term “American School” was coined in the same year by Nott, op. cit. (ref. 3).

${ }^{18}$ Stanton, op. cit. (ref. 6), p. 37 implies Morton simply appropriated phrenology for its popularity at the time.

${ }^{19}$ Fabian, op. cit. (ref. 5), p. 95 is the first to take Combe's contribution seriously, although only within the American national context. However, even Fabian suggests Morton's decision to "leave phrenology in an appendix" might be indicative of a lack of commitment.
} 
disciplinary position of Crania Americana dominated its initial reception on both sides of the Atlantic. ${ }^{20}$ Ultimately, the transatlantic world presented both opportunities and challenges for those hoping to claim Crania Americana on behalf of a variety of emerging human sciences. And it was precisely through these debates that disciplinary categories started to emerge.

\section{BANGING HEADS AT THE BRITISH ASSOCIATION}

On Tuesday 7th August 1839, Prichard stood to deliver his paper at the annual British Association for the Advancement of Science meeting, that year held in Birmingham. The mood was charged. Only a month before, the Metropolitan police had been sent to the city in order to contain Chartist crowds following Parliament's rejection of a major petition. ${ }^{21}$ Addressing Section D (Zoology and Botany), less than a mile away from the ruined scenes of the Bull Ring Riots, Prichard spoke on "The Extinction of some Varieties of the Human Race". ${ }^{22}$ In doing so, Prichard hoped to secure financial and institutional backing for natural historical studies of mankind, a discipline he had only recently begun to identify by the term 'ethnology'. 23

Up to that point, the British Association had not been particularly forthcoming. In the early 1830 s the organizing committee had been dominated by men from the University of Cambridge such as William Whewell. They promoted a hierarchical view of knowledge in

\footnotetext{
${ }^{20}$ On the role of plates in more local disciplinary debates, see Nick Hopwood, "Visual standards and disciplinary change: normal plates, tables and stages in embryology", History of science, xliii (2005), 239-303; Steven Shapin, "The politics of observation: anatomy and social interests in the Edinburgh phrenology disputes", in Roy Wallis (ed.), On the margins of science: the social construction of rejected knowledge (Keele, 1979), 139-178; Lorraine Daston and Peter Galison, Objectivity (New York, 2007).

${ }^{21}$ Malcolm Chase, Chartism: a new history (Manchester, 2007), pp. 81-2.

${ }^{22}$ The 1839 British Association meetings were centred on Victoria Square and the surrounding buildings,
} Report of the ninth meeting of the British Association for the Advancement of Science held in Birmingham (London, 1840), p. xxviii.

${ }^{23}$ Augstein, op. cit. (ref. 15), p. 25. 
which the Newtonian sciences occupied the pinnacle. This was reflected in the division of the British Association into different sections, with Section A (Mathematical and Physical Sciences) receiving the vast majority of funding. For fear of provoking religious controversy, the British Association had also excluded most of the emerging sciences of man: metaphysics, human geography and phrenology were all rejected. ${ }^{24}$ Nonetheless, the British Association was far from homogeneous. Under the leadership of the geologist Roderick Murchison in the late 1830 s, debate continued on the relative merits of Newtonian and Baconian philosophy alongside the extent to which the British Association should be allied to the government. ${ }^{25}$ Attendees at the annual meetings ranged from aristocrats and clergy to mechanics and schoolmasters. And, despite the rejection of phrenology, a medical section was established in 1836 in order to accommodate the large number of provincial physicians who attended each meeting. ${ }^{26}$

Prichard sought to establish a similar section for ethnology, promoting it as a discipline in its own right. Having spoken at the 1832 meeting in Oxford to a lukewarm reception, he knew a simple speech would not be enough. ${ }^{27}$ This year, things would be different. On the tables at the side of the lecture hall in Birmingham, Prichard displayed a set of loose lithographic plates which would later feature in Crania Americana (Figure 2). They had been sent directly by Morton following Prichard's election as a corresponding member of the Academy of Natural Sciences of Philadelphia earlier that year. ${ }^{28}$ On seeing these naturalistic illustrations of Native North and South American skulls, each finally shaded,

\footnotetext{
${ }^{24}$ Morrell and Thackray, op. cit. (ref. 15), pp. 273-87.

${ }^{25}$ A. D. Orange, "The beginnings of the British Association 1831-1851", in Roy MacLeod and Peter Collins (eds), The Parliament of Science: the British Association for the Advancement of Science 1831-1981 (Northwood, 1981), 43-64, pp. 53-59.

${ }^{26}$ Morrell and Thackray, op. cit. (ref. 15), p. xxi and pp. 287-288.

${ }^{27}$ Morrell and Thackray, op. cit. (ref. 15), p. 284.

${ }^{28}$ Prichard to Morton, 23 August 1839, Samuel George Morton Papers, American Philosophical Society (henceforth, APS) and Nasmyth to Morton, 18 June 1839. APS.
} 
observers were quick to describe the plates as "splendid" and "beautiful". ${ }^{29}$ Thomas Hodgkin, a founding member of the Aborigines' Protection Society, later wrote to Morton himself recalling "the pleasure of seeing a part of thy work displayed at the last meeting of the British Association". ${ }^{30}$ Prichard's message was clear. Whilst Britain's industrial towns fell into disrepair, the rest of the world was advancing its understanding of mankind. As the signature on each lithograph announced, these incredible images had been produced in the United States by American naturalists and artists. With Morton's plates there for all to see, Prichard confidently reminded his audience that, for Britain, "it would be a stain on her character, as well as a loss to humanity, were she to allow herself to be left behind by other nations in this enquiry". 31

\footnotetext{
${ }^{29}$ Prichard to Morton, 8 October 1839, APS.

${ }^{30}$ Hodgkin to Morton, 12 November 1839, APS.

${ }^{31}$ The report of the eleventh meeting of the British Association for the Advancement of Science held at Plymouth (London, 1842), p. 332.
} 


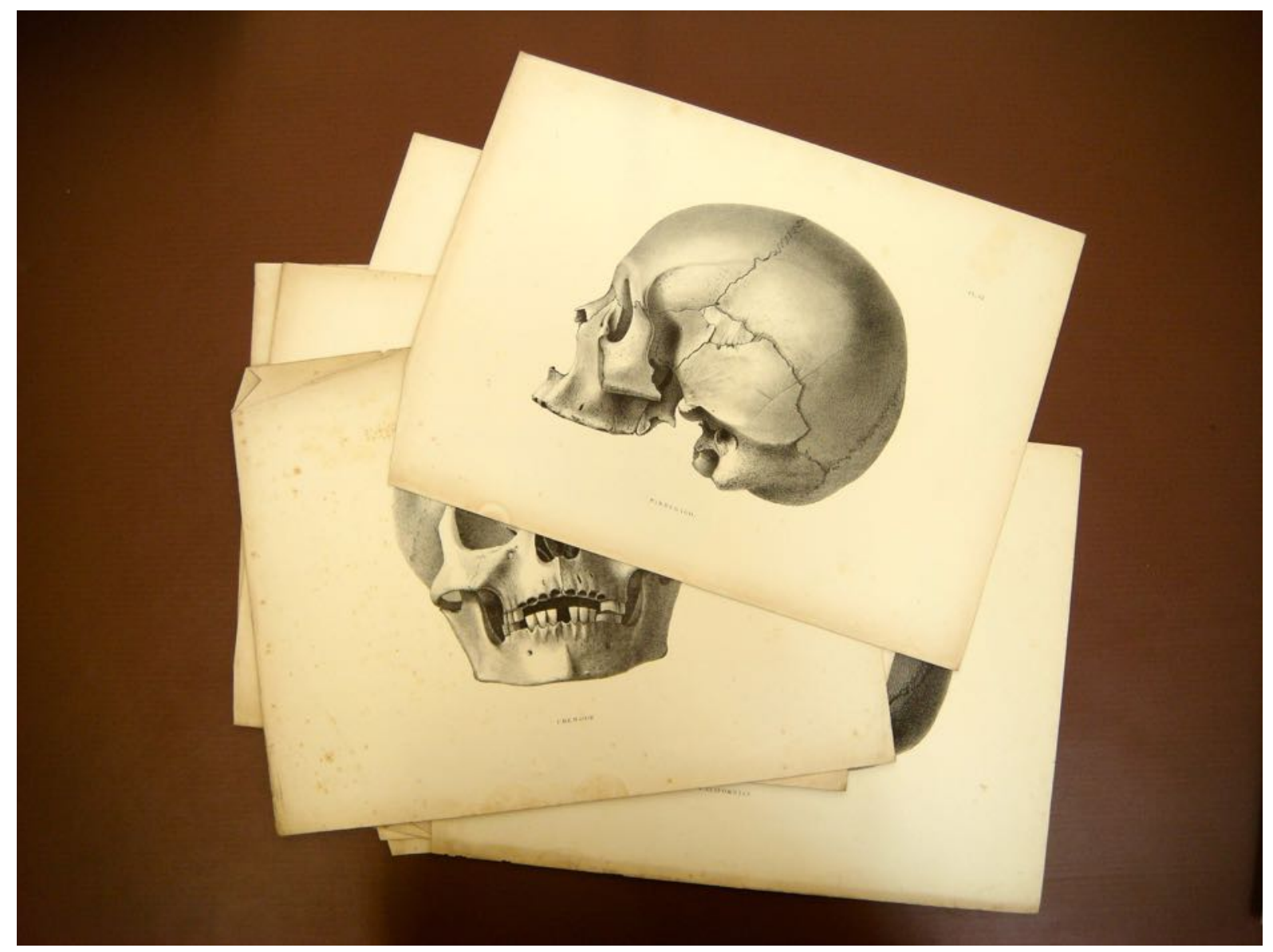

Figure 2: Loose lithographic plates printed to promote Crania Americana, Whipple Library, University of Cambridge.

The strategy seemed to work, at least in part. By the end of the meeting, Prichard had secured $£ 5$ for "Printing and Circulating a Series of Questions and Suggestions for the use of travellers and others, with a view to procure Information respecting the different races of Man". ${ }^{32}$ The British Association defined its own reputation on an international stage, and so could not afford to ignore the advancing status of American natural history. Indeed, William Harcourt, in his first presidential address at the York meeting of 1831, had warned against a world in which "colony after colony dissevers itself from the declining empire, and

${ }^{32}$ Report of the ninth meeting of the British Association, op. cit. (ref. 22), p. xxxvi. 
by degrees the commonwealth of science is dissolved". ${ }^{33}$ Harcourt chose an imperial metaphor to express his fear that specialization would lead to the disintegration of national science. Prichard played to these concerns. Morton's plates were presented both as an opportunity for Britain to reengage with its lost colony and to maintain a disciplinary connection with ethnology.

The specific choice to present craniological plates, rather than some other ethnographic illustration, also reflected Prichard's hope of carving out a new disciplinary space. The 1830 s saw the development of novel visual languages as disciplines including geology, astronomy and zoology all sought to gain institutional footing. ${ }^{34}$ The same was true for ethnology. ${ }^{35}$ In the first edition of Researches into the physical history of man, published in 1813, Prichard had followed Enlightenment scholars such as Blumenbach in assuming the importance of language and skin colour for determining the races of man. ${ }^{36}$ Not much had changed by the second edition of 1826 , in which Prichard cross-referenced linguistic and racial development in a long appendix. ${ }^{37}$ However, in 1836 Prichard began publication of the third edition of his Researches in five volumes. The first volume included nine lithographic plates, all of which depicted human skulls. An entirely new chapter had also been added entitled "National Forms of the Skull" in which Prichard declared, "Of all peculiarities in the form of the bony fabric, those of the skull are the most striking and distinguishing." ${ }^{38}$ The questionnaire he prepared following the British Association meeting reflected this too, in

\footnotetext{
${ }^{33}$ First report of the proceedings, recommendations, and transactions of the British Association for the Advancement of Science (York, 1832), p. 18.

${ }^{34}$ Martin Rudwick, "The emergence of a visual language for geological science 1760-1840”, History of science, xiv (1976), 149-95, pp. 149-50.

${ }^{35}$ George Stocking, "What's in a name? The origins of the Royal Anthropological Institute”, Man, iii (1971), 369-90, p. 371 notes the lack of institutional embodiment for ethnology in the mid-1830s.

${ }^{36}$ Augstein, op. cit. (ref. 15), p. 117.

${ }^{37}$ James Cowles Prichard, Researches into the physical history of mankind (London, 1826), vol. i, pp. 531-44.

${ }^{38}$ James Cowles Prichard, Researches into the physical history of mankind (London, 1836), vol. i, p. 275.
} 
which he reminded recipients that "the head is so important as distinctive of race". ${ }^{39}$ Prichard also demarcated three broad forms of the skull including the "symmetrical or oval", the "narrow and elongated", and the "broad and square-faced". "With this in mind, we can better appreciate Prichard's choice of Morton's images in 1839. It was precisely during this period that Prichard moved away from a focus on language and towards identifying the human skull as the distinguishing feature of different races. In doing so, he hoped to develop a new visual language, one that would secure ethnology as a distinct discipline.

Not everyone at the Birmingham meeting was convinced. Once Prichard had finished speaking, Hewett Watson, editor of the Phrenological journal in Britain during Combe's absence, stood to respond. His presence was no accident. From 1838 onwards, the Phrenological journal had organized its own annual Phrenological Association "independent of the British Association, although holding its meeting at the same times and places". By following the same circuit as the British Association, phrenologists such as Watson hoped to advance their own study amongst attendees "interested in the sciences relating to organic nature, and to man". ${ }^{41}$ Prichard's paper was a good opportunity. As the Phrenological journal later reported, Watson "felt it a duty on his own part, to state some phrenological facts bearing on the communication of Dr. Prichard... a department of knowledge, towards which Dr. Prichard was known to be hostile". ${ }^{42}$ This claim was not without foundation. In his 1835 Treatise on insanity, published in London, Prichard had previously suggested that "phrenology will not continue to make proselytes... it will be ultimately discarded as an hypothesis without foundation". ${ }^{43}$ When Combe responded in private correspondence,

\footnotetext{
${ }^{39}$ The report of the eleventh meeting of the British Association, op. cit. (ref. 31), pp. 332-3.

${ }^{40}$ Prichard, op. cit. (ref. 38), vol. i, p. 281.

41 “The phrenological association”, Phrenological journal, xii (1839), 29-35, pp. 29-35 (italics original).

42 "Phrenology and the British Association”, Phrenological journal, xii (1839), 412-14, p. 412.

${ }^{43}$ James Cowles Prichard, A treatise on insanity and other disorders affecting the mind (London, 1835), p. 333.
} 
Prichard simply dismissed him, explaining there was "want of sufficient evidence on so difficult a question". ${ }^{4}$

Despite Prichard's response, this debate actually had little to do with the quality of evidence. Indeed, both ethnologists and phrenologists alike privileged the human skull as the seat of national difference. Rather, at the British Association meeting in 1839, phrenology and ethnology vied for recognition and legitimation. In doing so, these emerging sciences of man contributed to their ultimate demarcation as distinct disciplines. For Prichard and Watson, there could be only one natural historical study of mankind. ${ }^{45}$ Watson understood well that any funding Prichard might secure, no matter how small a sum, would amount to institutional acceptance from the British scientific establishment, the first step towards securing a separate Ethnological Section at future meetings. ${ }^{46}$ In the hope of derailing these plans, Watson reminded Prichard's audience in Birmingham that:

the Edinburgh Phrenological Society [contains] probably the best collection of national crania in existence... and that in applying the funds of the Association in seeking further evidences, it would be going for that which was distant and dear, before that which was at home and of easy access.

He then addressed the speaker directly: "May I ask Dr. Prichard whether he has examined the evidences contained in the museum I have alluded to?". Prichard responded, "No. I have not had the opportunity of doing so", before Watson fired back, "That is enough. I can say no

\footnotetext{
${ }^{44}$ Prichard to Combe, 10 October 1836, NLS.

${ }^{45}$ The production of disciplines often relied upon the exclusion of others, Ellen Messer-Davidow, David Shumway and David Sylvan, "Introduction”, in Ellen Messer-Davidow, David Shumway and David Sylvan (eds), Knowledges: historical and critical studies of disciplinarity (Charlottesville, 1993), p. 10.

${ }^{46}$ This goal was finally realized in 1851 with the establishment of Section E (Geography and Ethnology), Withers, op. cit. (ref. 15), p. 168.
} 
more to one who asserts the insufficiency of evidences he has not examined." ${ }^{47}$ By December, this exchange had made its way back to Philadelphia. Combe complained to Morton that "Dr Prichard asked for funds from the British Association for investigating, but without the aid of Phrenology, the very points which you have accomplished". ${ }^{4}$

Watson's rhetorical move ultimately failed, and Prichard was awarded the $£ 5$. But his intervention illustrates how, in the same year in which Crania Americana was published, phrenologists and ethnologists each sought to establish distinct studies of mankind. With each discipline privileging the skull, Morton's plates were subject to competing interpretations. Following Watson's critique, another supporter of Prichard, George Thompson, rose to respond. He announced that it was "his conviction that the uncivilized races had heads equally well-formed as were those of their destroyers". Thompson also added, apparently "with a sarcastic laugh", that these races were not so different from "large-headed Englishmen... even Mr. Watson himself." This riled the phrenologist. Watson pointed to Morton's plates, “only a few feet distant”. Challenging the ethnological account, he directed the audience towards "the figure of a Pawnee skull", describing it as "villainously low". 49 Here, Watson's language contrasts sharply with Prichard's. Whilst Prichard opted for geometric labels ("symmetrical" or "narrow”), the phrenologist saw Morton's plates in moral terms ("villainous").

This difference in observational practice represents just one of the ways in which phrenology and ethnology came to be distinguished. For Prichard, the form of the skull was neatly separated from the character of the mind. In the third edition of Researches he devoted distinct chapters to "the Psychological Comparison of the Human Races" and "National Forms of the Skull" without reflecting on the relationship between the two. The chapter on

\footnotetext{
47 "Phrenology and the British Association", op. cit. (ref. 42), p. 413.

${ }^{48}$ Combe to Morton, 7 December 1839, APS.

49 "Phrenology and the British Association", op. cit. (ref. 42), pp. 413-14.
} 
skulls is full of dry anatomical detail ("the occipital foramen is more central") whilst the chapter on psychology is awash with moral assessments ("Hottentots... degraded and miserable"). ${ }^{50}$ Given that Prichard explicitly denied the existence of a material mind, this is perhaps unsurprising. ${ }^{51}$ But more importantly, his project did not rely on uncovering a connection between form and function. Ethnology was instead founded upon what Prichard described as "analogical investigation". ${ }^{52}$ The aim of studying different skulls was in fact the same as his earlier philological work: to establish a detailed taxonomy through which different races could be identified. In contrast, phrenology was absolutely committed to a material mind. The races of man could only be distinguished by connecting national character to the contours of the skull. For Watson, looking at a skull was precisely to look at human character. For Prichard, it was simply an opportunity to establish another homology whether physical, moral or linguistic - within a particular national type.

This contest, over the correct reading of both Crania Americana and its accompanying lithographs, came to dominate its reception in both Europe and the United States. In Britain, Prichard had a head start. The transatlantic publishing context separated these early lithographic plates from Morton's own text as well as Combe's phrenological appendix. With these out of the way, Prichard was free to read Morton's unique illustrations in terms of a new visual language, one he claimed as distinct to ethnology. From then on, the phrenologists were playing catch up.

\section{A PHRENOLOGICAL APPENDIX FROM SCOTLAND}

Shortly after Combe's arrival in Boston during the winter of 1838 , Morton introduced himself. The two were quick to strike up a friendly correspondence. At this time, prior to his

\footnotetext{
${ }^{50}$ Prichard, op. cit. (ref. 38), vol. 1, pp. 165-216 and pp. 275-321.

${ }^{51}$ Augstein, op. cit. (ref. 15), p. 29.

${ }^{52}$ Prichard, op. cit. (ref. 38), vol. 1, pp. xi-xvi.
} 
contact with Prichard, Morton still saw Crania Americana primarily as a contribution to phrenology. He had learned about the science whilst studying for a second medical degree at the University of Edinburgh in the early 1820s, even attending a couple of meetings of the Edinburgh Phrenological Society. On first mentioning the book to Combe, Morton wrote, "although I am imperfectly informed on the subject of Phrenology, I have been for some years engaged in collecting a mass of facts which will bear directly on the science". Before long, Morton had offered Combe the chance to write "a paper on the Phrenological development of the American Race" to accompany the book. ${ }^{53}$ At first, Combe was hesitant. All he had to go on was a copy of the prospectus. ${ }^{54}$ But after the Harvard surgeon John Warren showed him a set of loose lithographs in Boston, Combe quickly took Morton up on his earlier offer. ${ }^{55}$ From then on, Combe worked hard to complete the phrenological appendix, submitting the draft manuscript in April 1839. ${ }^{56}$

In correspondence, Morton urged Combe to use his essay to explain "the principles of Phrenology, \& their application to the heads of the American Race.. ${ }^{, 57}$ The phrenologist did not disappoint. Combe presented the study of national character as an essentially phrenological question. In his opening paragraph, he complained that the topic had "been investigated by philosophers in general, without any knowledge of, or reference to, the functions of the different parts of the brain". In Combe's eyes, Blumenbach's attention to skin colour and Prichard's interest in philology and anatomy marked them out as very different, ultimately flawed, intellectual enterprises. What made Morton's work phrenological, according to Combe, was his attention to the materiality of the mind. He followed "a more perfect method of investigation", one characterized by attention to "the

\footnotetext{
${ }^{53}$ Morton to Combe, 11 October 1838, NLS.

${ }^{54}$ Morton to Combe, 11 October 1838, NLS.

${ }^{55}$ Combe to Bache, 28 October 1838, APS.

${ }^{56}$ Morton to Combe, 1 April 1839, NLS.

${ }^{57}$ Morton to Combe, undated [1839], NLS (underlining original).
} 
relative magnitudes of the whole brain, and the relative proportions of the different parts of the brain, indicated by the national skulls". ${ }^{58}$ Combe also wanted to guide readers away from interpreting Crania Americana within existing natural historical traditions. This was certainly a legitimate concern, with the North American review giving notice of Morton's prospectus under the heading "natural history" in $1838 .{ }^{59}$ For Combe, natural history without natural philosophy was just cataloguing. Only phrenology allowed one to understand the workings of politics, empire and industry. Earlier in the century, the phrenologists in Edinburgh had clashed with their opponents over exactly this: the extent to which social and political issues should be manifest in mental science. ${ }^{60}$ This problem now made its way across the Atlantic. Without phrenology, Combe argued in Philadelphia, "these skulls are mere facts in Natural History, presenting no particular information as to the mental qualities of the people." ${ }^{\prime 61}$

For Combe, as for Prichard, the plates were crucial. Although unaware of Prichard's interest in Crania Americana at this point, Combe too hoped to claim Morton's illustrations on behalf of a new visual language, but this time characteristic of phrenology. Morton concurred in his own preface, explaining that Combe's essay would enable the reader "to apply Phrenological rules to every skull in the series here figured". ${ }^{2}$ But in order for this argument to work, Combe needed to introduce a point of reference. Shortly after completing the draft in April 1839, he convinced Morton to commission an additional lithograph, featured as Plate 71 in the final volume (Figure 3). It depicts a "Swiss" skull from the collection of the Edinburgh Phrenological Society, one which Combe carried with him as part of his lecture tour. It was with this illustration that Combe hoped to secure his phrenological reading. As he wrote in the appendix:

\footnotetext{
${ }^{58}$ Samuel Morton, Crania Americana (Philadelphia, 1839), p. 269.

59 "New publications", North American review, xlvii (1838), 263-72, p. 268.

${ }^{60}$ Shapin, op. cit. (ref. 20).

${ }^{61}$ Morton, op. cit. (ref. 58), p. 275.

${ }^{62}$ Morton, op. cit. (ref. 58), p. iv.
} 
[By] comparing the dimensions of this Swiss skull as they appear to the eye in the plate, with those of the other skulls delineated in this work, all being drawn as large as nature, their relative proportions will become apparent. ${ }^{63}$

Once again, the material form of the illustrations mattered. With the lithographer John Collins charging $\$ 8.75$ per commission, Morton initially hoped to lower costs by having the Swiss skull drawn at a reduced size. ${ }^{64} \mathrm{He}$ informed Combe that it would be "lithographed at least at half size... which I hope will answer the purpose." ${ }^{65}$ For Combe, this would not do. The skulls all needed to be lithographed to the same scale in order to allow for comparison by eye. On seeing a proof of the Swiss lithograph whilst in Philadelphia, Combe eventually persuaded Morton to have it redrawn at full size. ${ }^{66} \mathrm{He}$ also ensured that the lithograph accurately indicated the major phrenological divisions, explaining in his appendix that "the space included in D, A, B, denotes the dimensions of the anterior lobe devoted to intellect" whereas "the space included in E, C, D, to manifest the moral sentiments". ${ }^{67}$

\footnotetext{
${ }^{63}$ Morton, op. cit. (ref. 58), p. 278.

${ }^{64}$ Receipts of Crania Americana, C0199, Princeton University Library (henceforth, Receipts of Crania Americana).

${ }^{65}$ Morton to Combe, undated [1839], NLS.

${ }^{66}$ Morton to Combe, 1 April 1839, NLS.

${ }^{67}$ Morton, op. cit. (ref. 58), p. 279.
} 


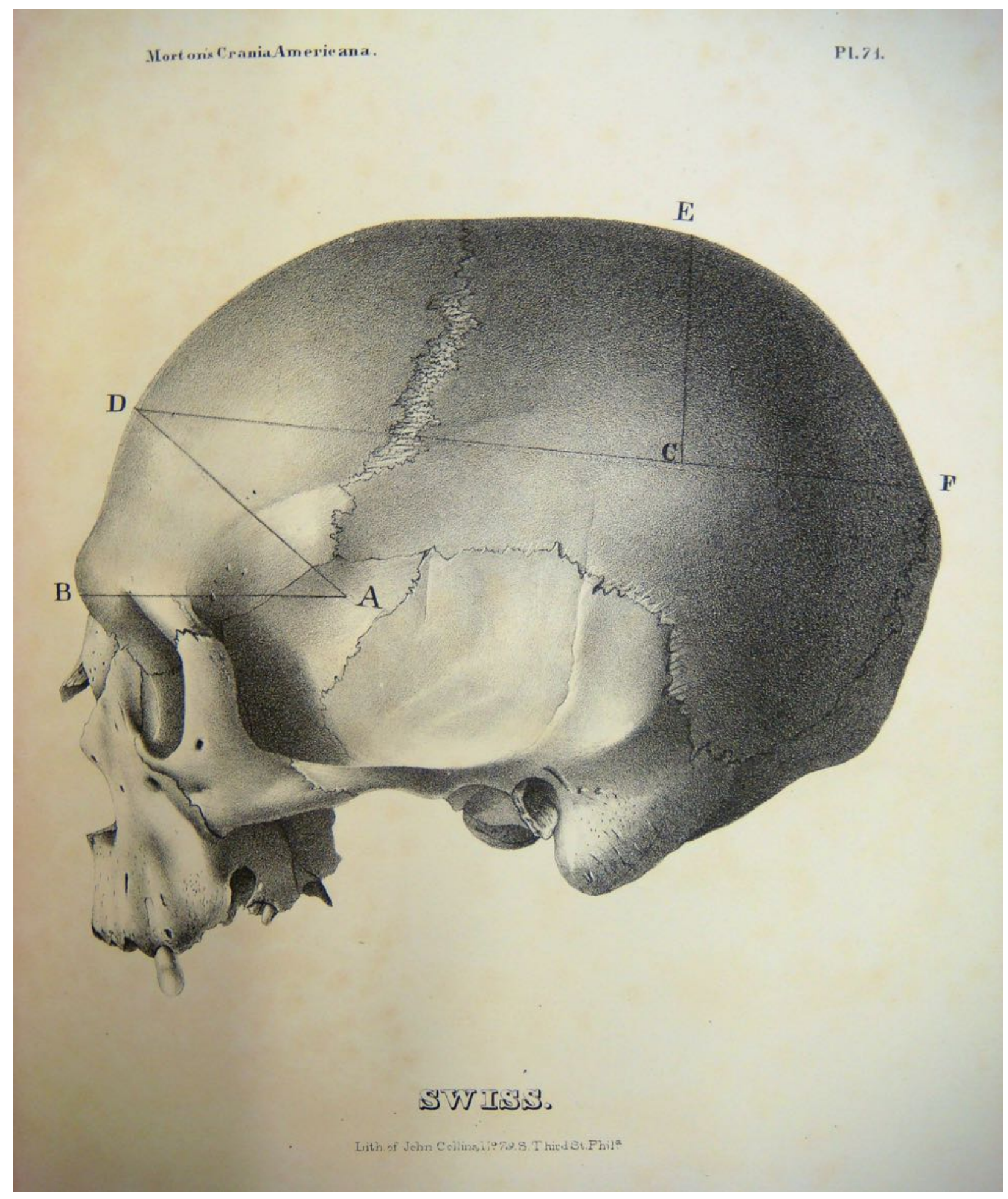

Figure 3: Plate 71, Swiss, Crania Americana, Whipple Library, University of Cambridge. 
Soon after the printing of this final lithograph, word reached Combe of Prichard's success in Birmingham. The early reception of Morton's plates in Britain then fed back into the printing and publication of Crania Americana in Philadelphia. With this disciplinary challenge underway, the appendix took on even greater importance. Earlier in the year, Morton had informed Combe that it would need to be printed in a smaller type than the rest of the book. Morton tried to account for this in terms of the lack of support from his publisher, writing, "I am not backed by some responsible \& enterprising publisher: but having to meet every expense from my own purse". ${ }^{68}$ This chimed with a narrative in which American naturalists considered it difficult to secure patronage at home: most notably, John James Audubon had found it necessary to sail to Britain in order to seek both subscribers and a publisher for his extraordinary Birds of America ${ }^{69}$ But, on hearing the news of Prichard's display at the British Association, Combe put his foot down. In the end, Morton relented, and in October 1839 he recorded that the "Appendix to my book is nearly printed in the same type as my own" ${ }^{70}$ Combe also tried to persuade Morton to superimpose phrenological divisions onto his earlier plates. However, by this time, it was too late. Morton reasonably informed Combe that, "as the whole edition of every plate is already struck off, it will not be in my power to insert marks for the centres of ossification \& causality". ${ }^{71}$ Still, Morton did make one concession. On Plate 40, "the Cotonay head", Collins added a small "X" (Figure 4). This indicated the point at which the parietal bone joins the sphenoid, from which the "reflecting organs" had been measured. ${ }^{72}$

\footnotetext{
${ }^{68}$ Morton to Combe, undated [1839], NLS (underlining original).

${ }^{69}$ Duff Hart-Davis, Audubon's elephant (London, 2003), p. 7.

${ }^{70}$ This is also confirmed on inspection of the printed text, Morton to Combe, 8 October 1839, NLS.

${ }^{71}$ Morton to Combe, undated [1839], NLS.

${ }^{72}$ Morton, op. cit. (ref. 58), p. 262.
} 


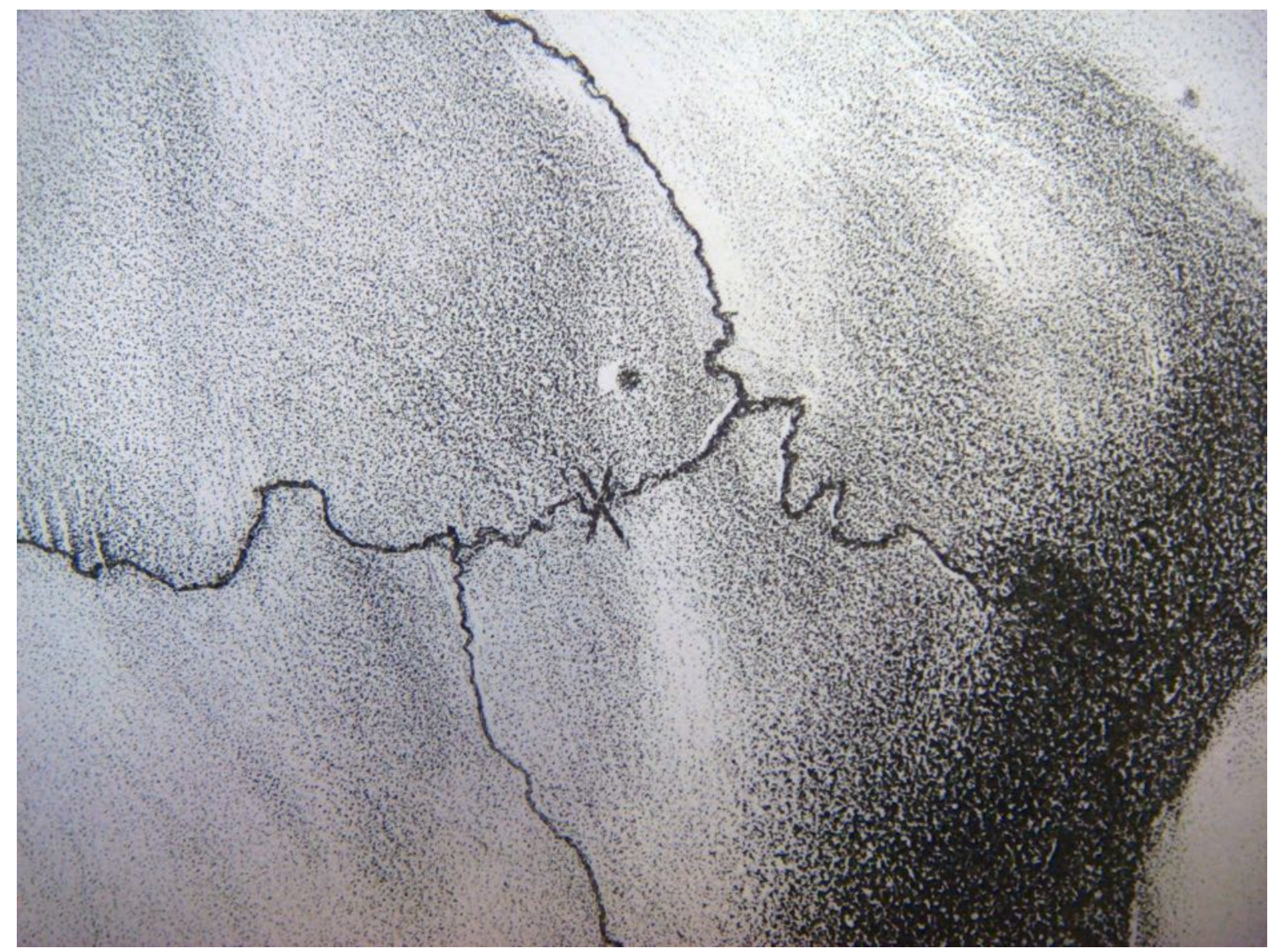

Figure 4: Detail from Plate 40, Cotonay, Crania Americana, Whipple Library, University of Cambridge.

Despite these successes in late 1839 , not everything went the phrenologists' way. As soon as he returned to Bristol following the British Association meeting in August, Prichard wrote to Morton describing the favourable reception the plates had received: "I took your beautiful plates to the meeting of the British Association at Birmingham where they were exhibited publicly and much admired." ${ }^{, 73}$ In particular, he informed Morton about the interest the plates had generated amongst his fellow ethnologists, rather than phrenologists such as Watson. In an attempt to cement this disciplinary connection, Prichard wrote, "My friend Dr Hodgkin... is particularly interested in the subject of ethnography... I will mention your book

\footnotetext{
${ }^{73}$ Prichard to Morton, 8 October 1839, APS.
} 
to him. ${ }^{74}$ Finally, Prichard highlighted his efforts in promoting Crania Americana in Britain, offering to help "accelerate the acquaintance of my countrymen with your work" ${ }^{75}$

At a time when Morton was embroiled in a troublesome working relationship with his alcoholic publisher, John Fuller, this news evidently pleased him. ${ }^{76}$ In fact, Prichard's early use of the plates at the British Association, ultimately prompted Morton to divide the entire edition of Crania Americana into two different states. In December 1839 Morton separated the final 500 printed copies into what he described as "two editions, the American and the Foreign" ${ }^{77}$ The "American edition" of 400 copies featured two dedications: one to John Phillips, Morton's assistant in Philadelphia and another acknowledging the help of William Ruschenberger, an American naval surgeon and colleague at the Academy of Natural Sciences of Philadelphia. ${ }^{78}$ Morton had something else in mind for the remaining 100 copies. ${ }^{79}$ As he explained to a despairing Combe in 1840, "I dedicated my work to Dr Prichard... he has shewn a great interest for the success of my work in several letters addressed to me, \& his communication to my friends". ${ }^{80}$ The "foreign edition" therefore featured three dedication pages. Phillips remained but Ruchenberger was omitted entirely. In his place, Morton inserted a dedication to his Irish uncle James Morton, and a separate sheet praising "the learned and ingenious author", James Cowles Prichard. Even more disturbing for the phrenologists, Morton explicitly linked his own publication to Prichard's ethnological project. The dedication went on to read that Crania Americana was "designed to illustrate a

\footnotetext{
${ }^{74}$ Prichard to Morton, 17 February 1840, APS.

${ }^{75}$ Prichard to Morton, 23 August 1839, APS.

${ }^{76}$ Combe to Morton, 11 October 1839, NLS.

77 [George Combe], “Crania Americana”, American journal of science, xxxviii (1840), 341-75, p. 375.

${ }^{78}$ Examples of the "American edition" can be found at the American Philosophical Society, the College of Physicians of Philadelphia, and the Academy of Natural Sciences of Drexel University. Copies of the "foreign edition" can be found at Cambridge University Library, Bristol University Library, and the Linnean Society.

${ }^{79}$ Morton to Combe, 13 December 1839, NLS.

${ }^{80}$ Morton to Combe, 24 May 1840, NLS.
} 
portion of the same interesting enquiry" as Prichard's Researches into the physical history of mankind which had recently entered into a third and expanded edition (Figure 5). 
JAMES COWLES PRICHARD, M. D., F. R. S., \&c. \&c. \&c.,

OF BRISTOL, ENGLAND,

THE LEARNED AND INGENIOUS AUTHOR

OF

"Researches into the Physical History of Mankind,"

THE FOLLOWING WORK,

WHICH IS DESIGNED TO ILLUSTRATE A PORTION OF THE SAME INTERESTING INQUIRY,

IS MOST RESPECTFULLY

DEDICATED.

Figure 5: The dedication to James Cowles Prichard is only found in the "foreign edition" state of Crania Americana, Bristol University Library. 
Combe did his best to convince Morton that this was an error. He warned him that:

Mr Hewett Watson intended to purchase three copies of your work at his own expense \& present them to public institutions... when he read the dedication to Dr Prichard he abandoned his purpose $!^{81}$

But it was too late. Early reviews in Britain were quick to spot the dedication, and many naturally assumed Crania Americana should be read as part of Prichard's ethnological project. The British and foreign medical review, published quarterly in London, helpfully informed its readers that "[the] volume is dedicated to our illustrious countryman, Dr. Prichard." Quoting the dedication directly the reviewer added, "We need scarcely add our own opinion that to no one could this work, 'which is designed to illustrate a portion of the same interesting enquiry,' be more appropriately inscribed'." In fact, the reviewer even recommended skipping over Morton's introductory essay, "since it contains little that will be new to the readers of Dr. Prichard's elaborate treatise." ${ }^{82}$ In bits and pieces, Crania Americana made its way back and forth across the Atlantic Ocean. Reading Morton's work clarified, and also sometimes complicated, disciplinary boundaries. By the end of 1839 , Prichard looked to have secured Crania Americana as an ethnological atlas. Still, the phrenologists did not give up. Back in the United States, Combe redoubled his efforts to manage this troublesome transatlantic publication.

\footnotetext{
${ }^{81}$ Combe to Morton, 31 May 1840, APS.

82 "Crania Americana”, British and foreign medical review, x (1840), 474-85, pp. 474-5.
} 


\section{APPOINTING A BRITISH PUBLISHER}

For Morton and his supporters on the East Coast, the reception of Crania Americana in Europe was at least as important as its success in the United States. Earlier in the century, episodes such as the discovery of the Gloucester sea serpent had fed the prejudices of European naturalists, many of whom believed American science to be untrustworthy. When the sightings of 1817 were confirmed as a hoax, the British geologist Gideon Mantell described them as just another "Yankee lie". ${ }^{83}$ But even Benjamin Silliman, editor of the prestigious American journal of science, had taken the sea serpent seriously. This, alongside the 1835 'Great Moon Hoax' reported in the Sun of New York City, seemed to confirm the misgivings of both Chambers's Edinburgh journal and the London and foreign quarterly review. ${ }^{84}$ The United States was considered a "country of sensations" supported by a "degrading and disgusting" press. ${ }^{85}$ Morton recognized this was especially true of natural historical studies of mankind, noting the field was "regarded with suspicion \& distrust". 86

Promoters of American science also worried about their dependency on European texts and technologies: book imports into the United States far exceeded exports throughout the nineteenth century, whilst the majority of locally-printed works were simply European reprints. ${ }^{87}$ This dependency extended to paper, ink and binding cloth, all of which were

\footnotetext{
${ }^{83}$ Chandos Brown, "A natural history of the Gloucester sea serpent: knowledge, power and the culture of science in antebellum America", American quarterly, xlii (1990), 402-436, p. 431.

${ }^{84}$ Michael Crowe, "New light on the moon hoax", Sky and telescope, (1981), 428-9.

${ }^{85}$ John Barton and Jennifer Phegley, "Introduction: 'An age of sensation... across the Atlantic'”, in John Barton, Jennifer Phegley and Kristin Huston (eds), Transatlantic sensations (Farnham, 2010), 1-22, pp. 4-12.

${ }^{86}$ Morton to Combe, 24 May 1840, NLS.

${ }^{87}$ James Green, "The rise of book publishing”, in Robert Gross and Mary Kelly (eds), A history of the book in America: an extensive republic, print culture and society in the new nation 1790-1840 (North Carolina, 2010), 75-127, p. 125.
} 
routinely sourced from European suppliers. ${ }^{88}$ Even the limestone used for Morton's lithographs was imported from Bavaria via New York at a cost of 10 cents per pound. ${ }^{89}$

Nonetheless, whilst early Philadelphia lithographers struggled to match the quality of French imports, the situation had changed considerably by $1839 .{ }^{90}$ The city housed six wellrespected lithography firms. These included John Collins of 79 South Third Street, responsible for the majority of lithographs found in Crania Americana, including Combe's Swiss skull, as well as those displayed at the British Association. ${ }^{91}$ Lithography also came to be understood as a means by which American science could establish itself as reputable on the global stage. ${ }^{92}$ Firms such as Thomas Sinclair, which purchased Collins's business during the publication of Crania Americana, specialized in natural history illustration. ${ }^{93}$ This specialization was accompanied by a move away from the realism favoured in the early nineteenth century, in which specimens were depicted as active in an environment. Instead, increased European trust in American natural history coincided with the portrayal, as in Crania Americana, of stationary specimens presented against a plain white background. ${ }^{94}$

On receiving his own copy of the final bound volume in February 1840, Silliman was therefore quick to recognize the potential value of Crania Americana in promoting American

\footnotetext{
${ }^{88}$ Jennifer Ambrose and Erika Piola, "The first fifty years of commercial lithography in Philadelphia”, in Erika Piola (ed.), Philadelphia on stone: commercial lithography in Philadelphia 1828-1878 (Philadelphia, 2012), 1-48, p. 11

${ }^{89}$ Michael Twyman, "Putting Philadelphia on stone", in Erika Piola (ed.), Philadelphia on stone: commercial lithography in Philadelphia 1828-1878 (Philadelphia, 2012), 49-78, p. 71.

${ }^{90}$ Ann Blum, Picturing nature: American nineteenth-century zoological illustration (Princeton, 1993), p. 52 and Ambrose and Piola, op. cit. (ref. 88), p. 3.

${ }^{91}$ Philadelphia directory (Philadelphia, 1839), p. 47.

92 Georgia Barnhill, “Transformations in pictorial printing”, in Robert Gross and Mary Kelly (eds), A history of the book in America: an extensive republic, print culture and society in the new nation 1790-1840 (North Carolina, 2010), 422-440, pp. 425-426

${ }^{93}$ Blum, op. cit. (ref. 90), p. 194.

${ }^{94}$ Blum, op. cit. (ref. 90), p. 48.
} 
science abroad. ${ }^{95}$ He reassured Morton that there was "no doubt it will do you great honor in Europe". ${ }^{96}$ For Silliman, Morton's personal reputation was also tied to the success of American national science. He went on to write that "you cannot be compensated except in reputation $\&$ in the consciousness of having added to the reputation of your country for the sacrifice of so many years". ${ }^{97}$ Waldie's journal of polite literature, a Philadelphia monthly, singled out Morton's plates in particular, reporting:

We have not see any thing of the kind from any European press, either English, French, or German, which exceeds the drawings of Mr. Collins in fidelity of representation, or in the beauty of execution or delicacy of finish. ${ }^{98}$

The Christian examiner in Boston even praised the presswork itself, calling Crania Americana, "typographically speaking, one of the most magnificent the country has produced". 99

Despite all this praise in his home country, Morton was well aware that getting his work noticed in Europe would not be straightforward. First and foremost he needed a British publisher. In this respect, the phrenologists had an advantage over Prichard. Whilst Combe toured the United States between 1838 and 1840, he remained in close contact with Morton through correspondence. He also made a number of stopovers in Philadelphia during the spring of $1839 .{ }^{100}$ During these visits, Morton was quick to recognize Combe's international reputation as the author of The constitution of man alongside his expertise in transatlantic

\footnotetext{
${ }^{95}$ Silliman took delivery of his own copy on 17 February 1840, Silliman to Morton, 19 February 1840, APS.

${ }^{96}$ Silliman to Morton, 27 March 1840, APS.

${ }^{97}$ Silliman to Morton, 19 February 1840, APS.

${ }^{98}$ Waldie's journal of polite literature, 31 January 1840, p. 10.

99 “Crania Americana”, Christian examiner, xxviii (1840), 248-52, p. 251.

${ }^{100}$ Combe to Morton, 4 April [1839], APS.
} 
publishing. In October he told Combe, "whatever publisher you recommend I will employ \& I will thank you to write to him on the subject". ${ }^{101}$ This opportunity allowed Combe to direct Morton towards a British publisher sympathetic towards phrenology. Three days later, Combe replied recommending "Messrs Simpkin, Marshall \& Co, London, as unexceptionable publishers, safe as to responsibility, punctual, \& attentive". ${ }^{102}$ By December, the decision had been set in ink. Morton sent Combe a short note: "I am extremely obliged for your communication and advice respecting the publication of my book in London, \& have accordingly put the names of Simpkin, Marshall, \& Co on my title page as the London publishers." ${ }^{103}$ This firm, based at Stationers' Hall Court, published numerous editions of Combe's own books, including Elements of phrenology and Outlines of phrenology. Simpkin, Marshall, \& Co also published the Phrenological journal from 1827. They even wrote a public testimonial in 1836 calling for Combe to be elected to the Chair of Logic at the University of Edinburgh. ${ }^{104}$ For audiences in Britain familiar with this episode (in which Combe was ultimately unsuccessful), the presence of Simpkin, Marshall and Co on the title page ensured that the phrenological import of Crania Americana could not be ignored entirely.

Even after choosing a publisher, there was still a lot Morton did not understand about the nature of transatlantic publishing. Combe was therefore eager to highlight his own expertise, carefully setting out the logistical challenge of shipping Crania Americana to Britain and getting it noticed. ${ }^{105}$ Morton had already suffered one calamity. On the night of Friday 27th December 1839, the brig J. Palmer foundered off the coast of Cape Cod. Forty

\footnotetext{
${ }^{101}$ Morton to Combe, 8 October 1839, NLS.

${ }^{102}$ Come to Morton, 11 October 1839, NLS.

${ }^{103}$ Morton to Combe, 13 December 1839, NLS.

${ }^{104}$ Testimonials on Behalf of George Combe, as Candidate for the Chair of Logic, in the University of Edinburgh (Edinburgh, 1836), pp. 71-72.

${ }^{105}$ Combe to Morton, 11 October 1839, NLS.
} 
copies of Crania Americana, destined for the British market, were lost to a tide of "unprecedented height". The next morning, locals combing the shoreline discovered only "some pieces of boxes" and a "waistcoat, with the name of, 'S. Browne', on the back of it". ${ }^{106}$ As Morton lamented in a letter to Combe, the books were "not insured... [and] my subscribers to the eastward have been prevented from obtaining their copies". ${ }^{107}$

Prichard already had a head start, so Combe was keen to avoid further delays. As soon as Crania Americana was published in December 1839, Combe begged Morton to "use the speediest means" to have a copy delivered to Watson in London. ${ }^{108} \mathrm{He}$ also informed Morton that Crania Americana would be subject to import duties on arrival in Britain. The lithographs in particular would prove expensive; with 78 illustrations at $1 \mathrm{~d}$ each, they added another $12 \mathrm{~s} 6 \mathrm{~d}$ per copy. ${ }^{109}$ Additionally, whilst Morton at first planned the work as a quarto with separate folio lithographs, he later agreed with Combe to incorporate both illustration and text into a single folio volume. ${ }^{110}$ Copies were then bound locally before leaving Philadelphia, making it more difficult for owners and booksellers to discard the phrenological appendix or separate out individual lithographs. ${ }^{111}$ But this too increased the costs associated with import, as another duty needed to be paid on arrival at $5 \mathrm{~d}$ per pound weight. ${ }^{112}$ Combe also warned Morton that London publishers would charge "the expenses of carriage to their warehouse, of all advertisements, and postages". What's more, as Simpkin, Marshall and Co paid accounts in arrears, Combe advised Morton that there was "no prospect of your realising

\footnotetext{
${ }^{106}$ Awful calamities; or the shipwrecks of December 1839 (Boston, 1839), pp. 22-3.

${ }^{107}$ Morton to Combe, 8 January 1840, NLS.

${ }^{108}$ Combe to Morton, 7 December 1839, APS.

${ }^{109}$ Combe to Morton, 23 December 1839, APS.

${ }^{110}$ Early copies of the prospectus described the text as "printed on fine paper, in imperial quarto", "Morton's Crania Americana", American medical intelligencer, i (1838), 403-405, p. 405.

${ }^{111}$ Morton employed J. G. Russell to undertake the majority of the binding, Receipts of Crania Americana.

${ }^{112}$ Combe to Morton, 23 December 1839, APS.
} 
any sum from London sales in less time than two years". ${ }^{113}$ In short, publishing Crania Americana in Britain would prove expensive and required capital upfront to pay duties and freight charges.

With Morton still paying back his workmen in Philadelphia, he could not easily afford the additional costs associated with a British publisher. ${ }^{114}$ Fortunately, his Irish uncle passed away early in 1840 , leaving Morton a large legacy. ${ }^{115}$ This solved the immediate funding problem. Still, in the face of Combe's evident expertise, Morton decided to hand control over to the phrenologist. Writing in January 1840, Morton informed Combe that he planned to "put the whole business at your disposal, with a thousand thanks for this additional proof of your friendship". ${ }^{116}$ Unaware of the influence Combe would later exert, for Morton this was simply a solution to dealing with a publication context he did not fully understand. But for Combe, this allowed him to manage the reception of Crania Americana much more closely than before, particularly in Britain. From then on, as Morton's appointed representative, Combe was able to instruct Simpkin, Marshall, \& Co on pricing, advertisements, presentation copies, and suitable reviewers.

\section{ANCIENT PERUVIAN HEADACHE}

In early 1840, Morton began to prepare a consignment of the "foreign edition" to replace that lost the previous December. By sail, the books would take between twenty-five and forty-five days to reach Liverpool, before being sent down to Simpkin, Marshall and Co in London. ${ }^{117}$ With little chance of securing an extended review of Crania Americana in the British press

\footnotetext{
${ }^{113}$ Combe to Morton, 11 October 1839, NLS.

${ }^{114}$ Morton still owed money to his lithographers and colourists as late as March 1842, Receipts of Crania Americana.

115 Morton to Combe, 23 July 1840, NLS.

${ }^{116}$ Morton to Combe, 8 January 1840, NLS.

${ }^{117}$ Fyfe, op. cit. (ref. 11), p. 180.
} 
during the interim, Combe did what he could to guarantee a phrenological reception back in the United States. On topics related to American natural history, British periodicals were known to pay attention to major East Coast quarterlies, such as the North American review, as well as more specialized scientific publications. ${ }^{118} \mathrm{~A}$ favourable review in the right place, Combe understood, would feed back into the British reception the following season. Once again, Combe's proximity to key figures within the American scientific establishment proved decisive. Whilst in New Haven during the February of 1840, he met with Benjamin Silliman, editor of the American journal of science and professor at Yale University. ${ }^{119}$ Silliman had just received his own copy of Crania Americana and was mulling over who to select as a reviewer. ${ }^{120}$ Initially, he had been considering the Philadelphia physician and botanist Benjamin Hornor Coates. But different reviewers provided different skills. Combe advised Silliman that Coates was "more of a naturalist". In contrast, Combe offered to "shew the high moral \& historical interest of the work". ${ }^{121}$ In the end, Silliman opted for the phrenologist. Unaware of the controversy this might cause back in Britain, he explained to Combe, "No man in this country - or probably in any other - can be so good a judge of the merits of this work as yourself.". 122

Combe quickly accepted. The format in particular was appealing. Silliman offered Combe a review in "any form $\&$ to any extent you choose". ${ }^{123}$ This provided an opportunity to address a number of issues left out of the appendix due to Morton's restrictions. Indeed,

\footnotetext{
${ }^{118}$ The American journal of science listed booksellers in London, Paris and Hamburg on its title page throughout the 1840s. Jonathan Topham, "Science, print and crossing borders: importing French science books into Britain 1789-1815”, in David Livingstone and Charles Withers (eds), Geographies of nineteenth-century science (Chicago, 2011), 311-44, p. 331 also notes how reviews acted as a means of transnational exchange during this period.

${ }^{119}$ George Combe, Notes on the United States of North America (Edinburgh, 1841), vol ii, p. 240.

${ }^{120}$ Secord, op. cit. (ref. 9), p. 227 invites us to consider the choice of reviewer.

${ }^{121}$ Combe to Morton, 19 February 1840, APS.

${ }^{122}$ Silliman to Combe, undated [1840], NLS.

${ }^{123}$ Silliman to Combe, undated [1840], NLS
} 
the final review submitted to Silliman occupied thirty-five pages compared to the twentythree permitted in Crania Americana. Additionally, Combe had written the appendix without access to Morton's finished text: he had only seen the lithographs and skulls. A review would therefore allow Combe to establish a phrenological connection with the main body of Crania Americana. ${ }^{124}$

Nonetheless, Combe still needed to negotiate other aspects of the format. Silliman had initially planned to print Combe's notice in the April issue under "the authority of your name". ${ }^{125}$ But Combe knew that, if his review was to be taken seriously back in Britain, it needed to be anonymous. He explained to Morton that "as I wrote the appendix for you, my name on the Review would have injured its influence. It would have made it appear like a notice written by the author". What's more, Combe specifically had the British reception in mind when he made this request, informing Morton that:

The article on your work will appear Editorially. I begged for this on your account \& my own. An Editorial notice has double the weight of a communicated one. It will tell more in your favour in Europe. ${ }^{126}$

Combe understood well that decisions concerning format in the United States had the potential to shape the reception of a review back in Britain.

With these points agreed upon, Combe set to work. The review opened with the usual pleasantries, praising Crania Americana and situating it within a transatlantic context. Combe pointed to the "beauty and accuracy" of the lithographic plates and anticipated "a cordial

\footnotetext{
${ }^{124}$ Combe to Morton, 19 February 1840, APS.

${ }^{125}$ Silliman to Combe, undated [1840], NLS

${ }^{126}$ Combe to Morton, 6 March 1840, APS.
} 
reception by scientific men not only in the United States, but in Europe". ${ }^{127}$ With this out of the way, Combe then embarked on an extended summary of Morton's introductory essay before pointing readers towards the core value of the work. "Thus far Dr. Morton has travelled over ground previously occupied by other naturalists", Combe wrote. What made Crania Americana exceptional, according to Combe, was its connection to phrenology:

[Dr Morton] has had the courage and sagacity to enter on a new path... with a view to elucidate the connection (if there be any) between particular regions of the brain and particular mental qualities of the American tribes. ${ }^{128}$

Tellingly, it is only at this point that Combe introduces a series of illustrations into his review. The review features six woodcuts in total, five of which are copies of Crania Americana lithographs. However, the initial woodcut depicts two human brains and is entirely new (Figure 6). The brains are presented side-by-side from a top-down perspective and identified by Combe as "the brain of an American Indian" and "the brain of a European". Additionally, the different lobes are labelled from A to D on each brain. Combe went on to explain, "[in] the American Indian, the anterior lobe, lying between AA and BB is small, and in the European it is large". Making the final link to phrenology, Combe informed his readers that the anterior lobe was responsible for "the intellectual faculties". ${ }^{129}$

The introduction of this particular woodcut at this particular point in the review is significant. There are no illustrations of brains in the entirety of Crania Americana. This woodcut therefore allowed Combe to forge a connection missing in the work itself: an inferior skull implied an inferior brain. As Combe made clear, "we use the cuts only to

\footnotetext{
${ }^{127}$ Combe, op. cit. (ref. 77), p. 341.

${ }^{128}$ Combe, op. cit. (ref. 77), p. 348.

${ }^{129}$ Combe, op. cit. (ref. 77), pp. 354-6.
} 
illustrate the fact that the native American and the European brains differ widely in the proportions of their different parts". It was precisely at the point in which Combe introduces phrenology that this woodcut appears. It is printed directly after the page in which Combe first claims "the necessity is very evident of taking into consideration the relative proportions of the different parts of the brain, in a physiological enquiry into the connection between the crania of nations and their mental qualities". ${ }^{130}$ Combe further reinforced this link by printing a woodcut copy of the "Swiss" skull from Crania Americana, complete with phrenological divisions, straight after the brain illustration. He then invited the reader to compare the two images, writing, "In this figure (Fig. 3,)... line $\mathrm{AB}$ denotes the length of the anterior lobe from back to front, or the portion of brain lying between AA and BB in figures 1 and 2". 131 Whilst Prichard certainly saw the skull as a key factor in national difference, he was unwilling to link this to a material mind. ${ }^{132}$ Indeed, there are no brain illustrations in any of Prichard's three editions of Researches into the physical history of mankind available at this time. But seeing this connection, Combe argued, was key to reading both Morton's text and images as contributions to phrenology. This review therefore challenged Prichard's use of Crania Americana as emblematic of a new visual language distinct to ethnology.

\footnotetext{
${ }^{130}$ Combe, op. cit. (ref. 77), pp. 354-6 (italics original).

${ }^{131}$ Combe, op. cit. (ref. 77), p. 358.

${ }^{132}$ Augstein, op. cit. (ref. 15), p. 29.
} 


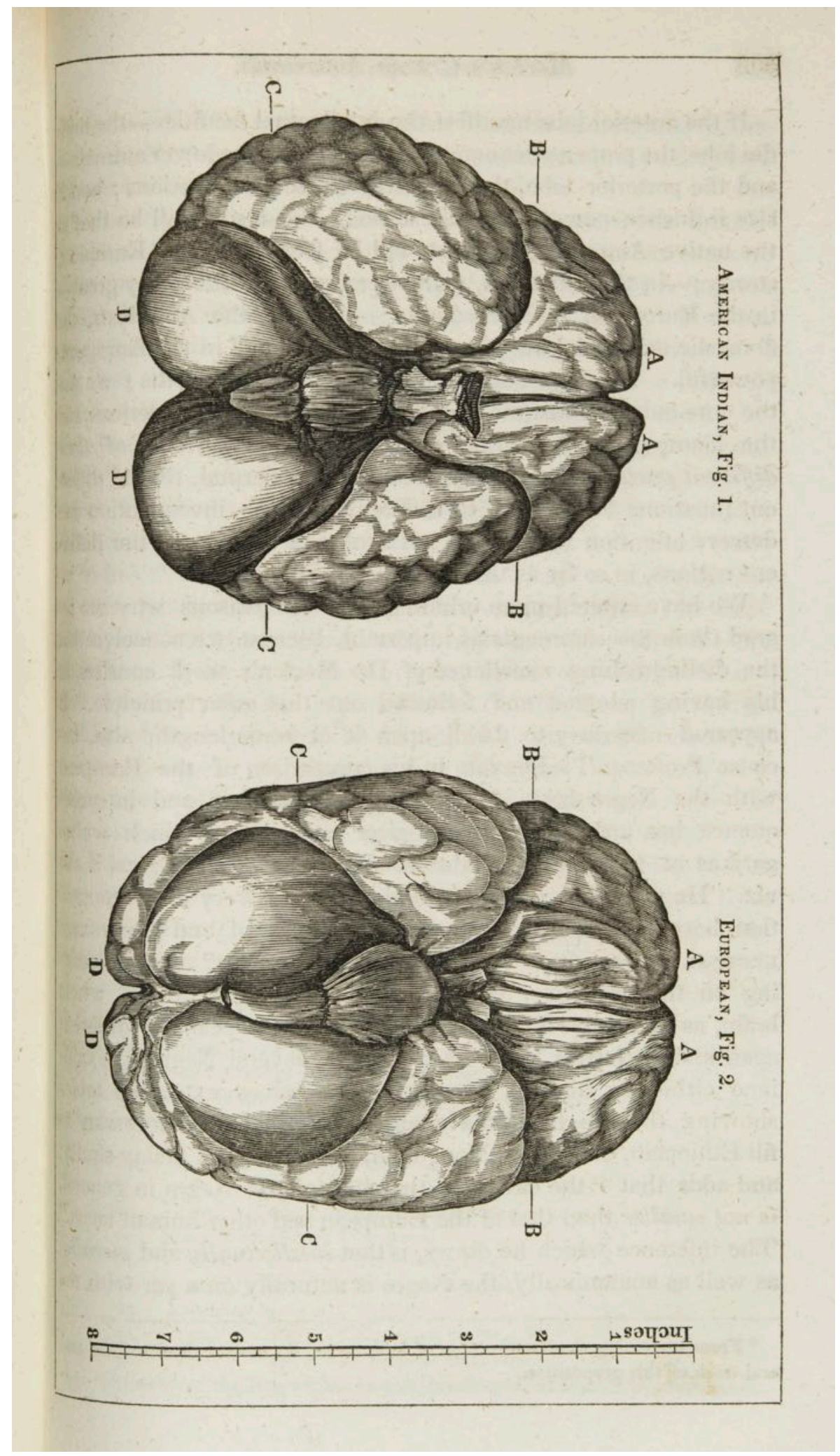

Figure 6: Woodcut illustrations of 'American Indian' and 'European’ brains, [George Combe], "Crania Americana", American journal of science, xxxviii (1840), 341-75, Bristol University Library. 
Despite his high praise for the work, Combe was not entirely uncritical of Crania Americana. The chapter on Peruvian skulls proved problematic. Morton explicitly denied that these specimens showed evidence of head-binding and artificial deformity. But this seemed to contradict Combe's phrenological assessment. Whilst preparing the review in February 1840, Combe wrote to Morton setting out his misgivings:

The only part of your work which puzzles me is that which treats of the ancient Peruvian heads, \& at once denies that they are compressed \& yet ascribes to them high civilization. ${ }^{133}$

Indeed, Morton had divided the Peruvian skulls into "two families": the "Modern Peruvians" and the "Ancient Peruvians". ${ }^{134}$ The Ancient Peruvians, according to Morton, typically featured a "low facial angle" and a "sloping forehead". Yet these "seemingly brutalised crania" had been discovered amidst the magnificent archaeological remains at Tiwanaku in South America, a site Morton compared to "the Theban catacombs". Morton therefore concluded that, whilst one might assume "a people with heads so small and badly formed would occupy the lowest place in the scale of human intelligence", they had in fact "attained a considerable degree of civilization and refinement". ${ }^{135}$

Combe, however, was not impressed. As he later wrote in the review, "[there] is a discrepancy between this description of these skulls and the civilization ascribed to their possessors". ${ }^{136} \mathrm{~A}$ number of readers soon picked up on the damning implications of Morton's analysis for phrenology. The North American review complained that "whatever may be the

\footnotetext{
${ }^{133}$ Combe to Morton, 28 February 1840, APS.

${ }^{134}$ Morton, op. cit. (ref. 58), p. 23.

${ }^{135}$ Morton, op. cit. (ref. 58), pp. 97-102.

${ }^{136}$ Combe, op. cit. (ref. 77), p. 363.
} 
views entertained with regard to the truth of the doctrine of the phrenologists, we are not apt to attribute a high degree of mental capacity to heads of an anti-Caucasian formation". ${ }^{137}$ John Augustine Smith, the New York physician and critic of phrenology also cited Morton's work in his Select discourses on the functions of the nervous system in opposition to phrenology. He too singled out the chapter on Peruvian skulls, ridiculing the idea that these Peruvians "had less talent than those whom they ruled". ${ }^{138}$ To make matters worst, Morton had already rejected one possible solution to this problem, writing in Crania Americana that "it is difficult to imagine by what complex contrivances the present shape could have been produced". ${ }^{139}$ Combe then queried Morton on this point, writing "[if] these skulls had been compressed by art, we could have understood that certain portions of the brain might have been only displaced, but not destroyed." 140

With the review close to press and no resolution in sight, Combe privately invited Morton to reconsider his position: "How can these contradictory facts be reduced to consistency with nature? ... I should be greatly obliged by your remarks by return of post." Morton did respond quickly, stating privately that he had "been hasty in considering it the cranial type of the nation... I cheerfully abandon a hypothesis which is at variation with nature \& analogy." ${ }^{\prime 42}$ However, with the book already printed, options for redress were limited. At first, Morton offered to publically retract his entire interpretation of the Ancient Peruvian skulls. At the beginning of March 1840, he sent Silliman a letter to this effect,

\footnotetext{
137 “Crania Americana”, North American review, li (1840), 178-186, p.180 (italics original).

${ }^{138}$ John Smith, Select discourses on the functions of the nervous system in opposition to phrenology (New York, 1840), pp. 133-4.

${ }^{139}$ Morton, op. cit. (ref. 58), p. 99.

${ }^{140}$ Combe, op. cit. (ref. 77), p. 363.

${ }^{141}$ Combe to Morton, 28 February 1840, APS.

${ }^{142}$ Morton to Combe, 3 March 1840, NLS (underlining original).
} 
suggesting it be printed at the end of the American journal of science review. ${ }^{143}$ But Combe intervened. He warned Morton that the letter "was too broad an admission of your own error, too strong a condemnation of what you had written about the ancient Peruvians, and too complete an abandonment of your own opinion \& inferences". With European trust in American natural history still hanging in the balance, Combe could not risk accusations of incompetence, particularly back in Britain. Combe therefore edited the letter, informing Morton that he had "avoided, as far as possible, this evil, \& at the same time made you state the essential fact that no. 4 is not the cranial type, $\&$ that you are engaged in procuring further information. ${ }^{144}$ In the final printed review, Morton's heavily-edited postscript simply read: "I wish to correct the statement, too hastily draw, that it is the cranial type of their nation... Signed, SAMUEL GEORGE MORTON". ${ }^{145}$

Combe wasn't the only barrier to Morton's retraction. The transatlantic publishing context also presented further complications. Initially, Morton had hoped to issue a second edition of Crania Americana soon after the first. The plan was to "wholly remodel" the chapter on Peruvian skulls. ${ }^{146}$ But there was a problem. Morton had already agreed not to publish a second edition "while any copies remain unsold in the hands of Messrs S. M. \& Co". Given the value of the stock soon to be sent to London, Morton could not risk violating the terms of his agreement with Simpkin, Marshall and Co. Furthermore, by March 1840, only a few copies had been bound and sent to reviewers. Indeed, Combe's private criticism had caused Morton to stall: both the "foreign" and the "American" edition remained at the printer's warehouse. With little prospect of a second edition any time soon, Morton therefore chose to make changes to those copies which had yet to leave Philadelphia. He redrafted the

\footnotetext{
${ }^{143}$ Morton to Silliman, 9 March 1840, NLS.

${ }^{144}$ Combe to Morton, 13 March 1840, APS.

${ }^{145}$ Combe, op. cit. (ref. 77), p. 375 (italics original).

${ }^{146}$ Morton to Combe, 21 March 1840, NLS.
} 
opening of his Peruvian chapter, making a few subtle changes to the wording on two of the four pages comprising sheet twenty-five. Morton then cancelled and replaced this entire sheet in all remaining copies. For the review, Combe only had access to Silliman's early unaltered copy but, as Morton explained, "[by] comparing the copy you received in that city with the other sent from here, you will see that I softened down my position as much as possible". 147 Following Combe's earlier advice, the changes were not extravagant. Morton simply omitted a line in which he described an Ancient Peruvian skull as "altogether peculiar". ${ }^{148}$

The "American edition" therefore existed in at least two different states: one with the original sheet twenty-five and one with the replacement. As the surviving copies of the "foreign edition" had yet to leave Philadelphia at this point, these only feature the replacement sheet. These changes therefore represent another means by which, within a transatlantic world of reviewers, printers and publishing agreements, Crania Americana took on an increasingly fragmented form. Combe's hope of securing a global phrenological reading looked increasingly unlikely.

\section{COMPRESSING AND SUPPRESSING REVIEWS}

For an expensive atlas such as Crania Americana, limited to 500 copies, the reception of a review could prove just as significant as the reception of the book itself. Particularly in Europe, where copies were even more scarce, a greater number of readers encountered Crania Americana as an octavo review rather than as a complete folio volume. Combe's notice in the American journal of science proved a particularly common source on both sides of the Atlantic. Certainly, the journal itself was considered noteworthy in Europe and the

\footnotetext{
${ }^{147}$ Morton to Combe, 24 May 1840, NLS.

${ }^{148}$ The copy of Crania Americana held by the College of Physicians of Philadelphia (ZXc5) contains the cancelled sheet signed twenty-five. The text corresponds to Morton's original manuscript, series iv, box 5, folder 2, Samuel George Morton papers, Library Company of Philadelphia (henceforth LCP).
} 
United States, as evidenced by a range of international resellers. Combe's April publication was also relatively early, with most American reviews not reaching the press until July 1840 and British reviews often being delayed even further into October and November. But most importantly, Combe's six woodcuts allowed readers to experience, albeit indirectly, what was for many the most novel aspect of Crania Americana: Morton's lithographs.

At the beginning of March 1840, Silliman's compositors in New Haven had finished setting the American journal of science review in type. By making use of local publishing networks, Combe ensured that both his notice and the accompanying illustrations moved in tandem, at least on the East Coast. Prior to publication in April, Combe arranged for offprints to be sent down to Philadelphia. ${ }^{149}$ There, Adam Waldie, publisher of the American phrenological journal, prepared for the review to be copied into the June number. Waldie knew that, if he wanted to use the original woodcuts, he would need to wait until after the publication of the American journal of science in April. This would have pushed his reprint back to July. As such, he decided to hire a local artist to copy the illustrations from the offprints. ${ }^{150}$ The American phrenological journal was then able to reproduce Combe's entire notice in June, a month before most other periodicals. Following this, American reviewers broadly followed Combe in acknowledging a connection between phrenology and Crania Americana. The Christian examiner in Boston praised the appendix, describing it as the "completion of the inquires and observations contained in the body of the work". ${ }^{151}$ John Bell's Eclectic journal of medicine in Philadelphia concurred. It singled out Morton's anatomical measurements as "the most valuable illustrations of philosophical craniology

\footnotetext{
${ }^{149}$ Combe to Morton, 6 March 1840, APS.

${ }^{150}$ This is revealed on close inspection of the American phrenological journal when compared to the American journal of science.

151 “Crania Americana”, op. cit. (ref. 99), p. 252.
} 
extant - the more so, indeed, as they are followed by a table of Phrenological Measurements". 152

Still, there was a limit to the power of Combe's notice, even in the United States. ${ }^{153}$ The July number of the quarterly North American review had likely gone to press prior to the publication of the April number of the American journal of science. Without Combe's prompt, the reviewer simply situated Crania Americana amidst "the learned and philosophical works of Blumenbach and Prichard", much to the phrenologist's disdain. ${ }^{154}$ Further west in Ohio, the Ladies' repository offered another alternative reading. This Methodist monthly operated in a world both geographically and intellectually distinct from Yale University and the Academy of Natural Sciences. Here, Crania Americana was introduced as a work of natural theology. The journal informed its female readership that "Man stands at the head of the animal kingdom... He is properly styled, 'lord of the lower world"'. This Biblical account of man's place in nature, the Ladies' repository suggested, also applied to different races. In support of this, it copied out a "description of these several varieties or races... from Dr. Morton's Crania Americana". ${ }^{155}$ Less than a decade earlier, the remaining Shawnee tribes in Ohio had been forcibly relocated west of the Mississippi River. ${ }^{156}$ In the wake of Andrew Jackson's policy of Indian removal in 1830, it is perhaps unsurprising to find the "American Race" recorded in this particular journal as "averse to cultivation, and slow in acquiring knowledge; restless, revengeful, and fond of war"' ${ }^{157}$

\footnotetext{
152 “Crania Americana”, Eclectic journal of medicine, iv (1840), 96-9, p. 99.

${ }^{153}$ Extracts proved central for shaping and reshaping meaning, as noted within the British national context by Gowan Dawson, Richard Noakes, and Jonathan Topham, "Introduction”, in Geoffrey Cantor, Gowan Dawson, Graeme Gooday, Richard Noakes, Sally Shuttleworth, Jonathan Topham (eds), Science in the nineteenth-century periodical (Cambridge, 2007), 1-36, p. 33.

154 “Crania Americana”, op. cit. (ref. 137), p. 173.

155 “Man”, Ladies' repository, i (1841), 72-74, p. 72.

${ }^{156}$ Jerry Clark, The Shawnee (Kentucky, 2007), p. 25.

157 “Man”, op. cit. (ref. 155), p. 73.
} 
In Britain as in Ohio, both Crania Americana and Combe's review were not always read as he would have wished. Prichard continued to promote his ethnological account wherever he could. On receiving his own copy, signed by the author, Prichard presented Morton's work at a meeting of the Royal Geographical Society. There he praised Morton's lithographs, describing the "accuracy of his delineations", before again linking Crania Americana to the ethnological project of the Aborigines' Protection Society to which Morton had recently been elected an honorary member. ${ }^{158}$ This "valuable work", Prichard told the Royal Geographical Society, contained "specimens of the skulls of all the aboriginal races in America, many of which have now become extinct". ${ }^{159}$ Prichard also used his influence within the medical profession to arrange a favourable notice in the British and foreign medical review, edited by John Forbes in London. He later boasted that, "The first review of it written in this country was made by a friend of mine". ${ }^{160}$ Morton made things easier, having sent Prichard's copy ahead of the shipment to Simpkin, Marshall and Co. Sure enough, the review was dismissive of phrenology, informing its readers that "we suspect the phrenological student needs more guidance than he will find here, in order that his conclusions may be satisfactory." The review also featured its own woodcut copies of Morton's plates. Picking up on Combe's anxiety about the Ancient Peruvian skulls, the British and foreign medical review selected a series of compressed and uncompressed heads. The author then concluded that, in the case of compressed specimens, phrenology was useless as the "relative position of the organs will be so changed that common rules for admeasurement will not apply to them". But here, by inviting the reader to notice the similarity between compressed and uncompressed heads, the author also presented a more

\footnotetext{
${ }^{158}$ Certificate of membership to the Aborigines' Protection Society, 23 January 1839, APS.

${ }^{159}$ James Cowles Prichard, “Crania Americana”, Journal of the Royal Geographical Society, x (1841), 552-561, p. 552.

${ }^{160}$ Prichard to Morton, 24 March 1841, APS.
} 
general problem: if phrenologists could not discern between natural and deformed skulls, then how could they guarantee the validity of their conclusions? He went on, writing, "and then the question arises whether these rules are applicable to uncompressed crania (such as that in fig 1.), of which the form so much resembles that of the skulls that have been submitted to the process". ${ }^{161}$

In London, the introduction of original woodcuts allowed the British and foreign medical review to challenge Combe's reading of Morton's lithographs. Rather than proof of phrenology, they now seemed to reveal its absurdity. This was made possible thanks to Prichard's early receipt of Crania Americana. Other reviewers sympathetic towards the ethnologist did not have such easy access. Indeed, Combe, was making things difficult. Morton had put him in charge of issuing presentation copies from Simpkin, Marshall and Co's stock, with recipients including David Craigie, editor of the Edinburgh medical and surgical journal, and James Kennedy, a regular for the Medico-chirurgical review. ${ }^{162}$ Predictably, both these journals printed notices either favourable or neutral towards phrenology. ${ }^{163}$

With access to Crania Americana under Combe's control, others were not so lucky. Most prominently, Robert Jameson, Regius Professor of Natural History at the University of Edinburgh and editor of the Edinburgh new philosophical journal, did not receive a presentation copy. This wasn't too much of a shock. Jameson was known to be hostile to phrenology, having lectured against the subject in the $1820 \mathrm{~s} .{ }^{164}$ But, whilst Crania Americana itself proved difficult for him to acquire in Edinburgh, the American journal of

\footnotetext{
161 “Crania Americana”, op. cit. (ref. 82), pp. 483-5.

${ }^{162}$ Combe to Morton, 20 August 1840, APS.

163 "Crania Americana”, Edinburgh medical and surgical journal, liv (1840), 443-468 and "Crania Americana”, Medico-chirurgical review, xxxiii (1840), 434-464. For an assessment of these reviews by the phrenologists, see "The quarterly medical journals", Phrenological journal, xiv (1841), 89-94.

164 “Phrenology and Professor Jameson”, Phrenological journal, i (1824), 55-58, p. 56.
} 
science did not. Jameson therefore chose to reprint Combe's review instead. ${ }^{165}$ However, as the phrenologists soon discovered, the reprint had been subject to heavy editing. Combe later identified this in a letter to Morton, writing that Jameson had omitted "all notice of the direct bearing of Phrenology on the Crania Americana \& all mention of my name as in any way connected with the work". ${ }^{166}$ This was a fair assessment. Jameson had deleted most paragraphs which either mentioned or supported phrenology. These included an extract from Crania Americana in which Morton declared, "I am free to acknowledge... that there is a singular harmony between the mental character of the Indian, and his cranial developments, as explained by phrenology”. Once again, Morton's plates proved a point of contention. Unlike in Philadelphia, Combe could not control the use of his woodcuts so easily. Jameson copied a number of these into his own journal but, crucially, left out the figures of the "Indian" and "European" brains, alongside the "Swiss" skull and accompanying text. The Phrenological journal provided an accurate analysis when it stated that "Mr Combe's index figure... is omitted: thus, the phrenological explanation of the four figures is suppressed in that Journal". ${ }^{167}$ Through careful editing, Jameson re-packaged Combe's review in Edinburgh to promote a very different reading. With these two woodcuts in absence, along with all mention of phrenology, Crania Americana could simply be described as a work of "the natural history of the native inhabitants of the New World". ${ }^{168}$

By October 1840 the reception of Morton's work seemed to have further fragmented on both sides of the Atlantic: readers interpreted Crania Americana in traditions ranging from natural history and ethnology, to natural theology and phrenology. Still, as Morton's

\footnotetext{
165 "Comparative view of the skulls of the various aboriginal nations of North and South America", Edinburgh new philosophical journal, xxix (1840), 111-39.

${ }^{166}$ Combe to Morton, 18 July 1840, APS.

167 "Professor Jameson's illustrations of a convenient method for pruning reviews that contain inconvenient opinions", Phrenological journal, xiii (1840), 303-14, pp. 312-13 (italics original).

168 "Comparative view”, op. cit. (ref. 165), p. 111.
} 
appointed representative in Britain, Combe still maintained a considerable amount of influence over Simpkin, Marshall and Co. He therefore hoped to use the cheap periodical press, rather than just the prestigious quarterlies and monthlies, to shift the balance back in his favour. Advertising was central to this strategy. In November 1840, Combe arranged for a full-page advertisement to be printed and inserted into Chambers' Edinburgh journal alongside a range of other monthlies which had yet to notice the work (Figure 7). Chambers' Edinburgh journal itself was developing an overseas connection at this time, available for just a couple of pence in both the United States and Britain. ${ }^{169}$ To reach such a broad audience, Combe needed to print 60,000 copies of the notice, each featuring six carefullyselected extracts from both American and British reviews. Quotes from the sympathetic Medico-chirurgical review and the Edinburgh medical and surgical review appeared alongside Combe's own American journal of science notice. Another extract from the Phrenological journal read, "The beautiful lithographic drawings by which this publication is so copiously illustrated, render it worthy of a place by the side of the large works of Gall and Vimont." ${ }^{170}$ Thus Crania Americana was presented as one amongst a range of phrenological atlases, from Franz Joseph's Gall's Anatomie et physiologie du système nerveux to Joseph Vimont's Traité de phrénologie humaine et comparée.

But it wasn't just through the choice of extracts that Combe hoped to nudge readers towards a phrenological interpretation. He also arranged for the opposite page to feature an advertisement for his own phrenological works. The economics of binding facilitated this, with Combe pointing out that the "expense of stitching to the Journals is the same for one page as for four". ${ }^{171}$ Readers therefore encountered this advertisement for Crania Americana within a few pages of, or in some cases directly opposite, a notice for Combe's own System of

\footnotetext{
${ }^{169}$ Fyfe, op. cit. (ref. 11).

${ }^{170}$ Combe to Morton, 4 November 1840, APS.

${ }^{171}$ Combe to Morton, 4 November 1840, APS.
} 
phrenology and the Phrenological journal. The notice also promoted the "People's Edition" of The constitution of man in double column at $1 \mathrm{~s} 6 \mathrm{~d}$ just across from Morton's folio volume at $£ 610$ s. This odd juxtaposition is better understood when we appreciate the function of the advertisement to establish Crania Americana as a phrenological work amongst as broad an audience as possible. 
In the Press, and will be published on 1st March 1841,

OURNAL OF A PHRENOLOGICAL VISIT TO THE UNITED STATES OF AMERICA, in 1838, 1839, and 1840. By George Combe.

Lately published, in $12 \mathrm{mo}$, pp. 382 , price $4 \mathrm{~s}$, the Fifth Edition; and also in royal 8vo, pp. 110, double columns, price 1s. 6d., "The People's Edition," of

THE CONSTITUTION OF MAN CONSIDERED IN RELATION 1 to External Objects. By George Combe.

This Work has gone through six editions in America, and been translated into several of the continental languages of Europe. Thirty-seven thousand copies of it have been sold in Great Britain and Ireland.

Also lately Published, in 1 vol. 18mo, Price 1s. 6 d.

THE SCHOOL EDITION of the CONSTITUTION OF

MAN. Abridged for the Use of Families and Schools, with Questions appended to the Chapters, reprinted from the American School Edition.

\section{LATELY PUBLISHED,}

A SYSTEM of PHRENOLOGY. By George Combe, A Fourth Edition, 2 vols. 8vo, pp. 933, with three plates and sixty-one illustrations on wood, price 2ls. bds. This work has been reprinted in the United States, and translated into French and German. It presents a full view of the science of Phrenology and its applications.

GLEMENTS of PHRENOLOGY. By George Combe, C. Fourth Edition, improved and enlarged. 12mo, pp. 194, with six plates and 24 cuts on wood, price $3 \mathrm{~s}$. $6 \mathrm{~d}$.

THE FUNCTIONS of the CEREBELLUM by Drs GaLL, Vimont, and Broussais, translated from the French by George Coмre. In 1 vol. $8 \mathrm{vo}, \mathrm{pp} .390$, price $8 \mathrm{~s}$.

ConTents.-Instinct of Reproduction a Function of the Brain-Action of the Brain on the External Organs-Action of External Organs on the Brain-Proof from the state of health-Proofs from the state of disease-Influence of Castration from the statellum-Diseases of the Cerebellum-Cases by Monsr. Serres, \&c. Dubois, Falret, \&c.- Additional cases collected by the translator.

UTLINES of PHRENOLOGY. Ry George Combe. 8vo, pp. 33. Fifth Edition. Illustrated by Engravings on Wood, price ls.

DOPULAR EDUCATION; its Objects and Principles elucidated. By George Combe. 8vo, pp. 80. Price ls. 6 d.

In Quarterly Numbers, price 2s. 6d. each,

THE PHRENOLOGICAL. JOURNAL AND MAGAZINE OF MORAL SCIENCE:

A New Series of the Phrenological Journal was commenced on the 1st of December 1837, and has been regularly published every three months. The contents of each Number of the Phrenological Journal consist of Essays upon Phrenology as a department of physiological science, or exhibiting its varied and important applications to the most interesting questions of social and moral philosophy-Cases and Facts illustrative of the science, and its application to legislation, medicine, atd the arts of life-Reviews and Lists of New Publications connected witt the same subjects-Critical Notes on the opinions of authors and celebrated men-and copious Intelligence respecting opinions of authors Phrenology, and upon various other topics connected with Mental and Moral Science. As it is the only periodical of its kind published in Britain, the Phrenological Journal is highly useful to phrenologists, and must be held an indispensable addition to every good library.

Maclachlan, Stewart, \& Co., Edinburgh ; Longman \& Co., and StMromin, Marshall, \& Co., London; and all other Booksellers.

Figure 7: Advertisement featured alongside Crania Americana in Chambers' Edinburgh Journal. 
Advertisements then did not simply act as a means to shift stock. However, this tactic was always limited by the reality of who could access the spaces in which Crania Americana was held. Readers of Chambers's Edinburgh journal might be members of mechanics' libraries, but they would be hard pressed to come across a copy of Morton's folio there. As the decade wore on, it became more and more evident that Crania Americana could only be found in libraries frequented by gentlemen of science. Certainly the work was expensive. But with a limited number of copies, both Morton and Combe also targeted the more prestigious European institutions. In Britain, both the Royal Society and the Linnaean Society held copies. ${ }^{172}$ The London Mechanics' Institute did not. ${ }^{173}$ A letter from J. J. Flanders, a semiliterate man from New York, further reminds us of the difficulties working-class men and women, along with slaves and Native Americans, continued to face in accessing expensive folios. Flanders explained to Morton that he had heard of "a work caled the Crania Americana written by you acompaned with ingravins of skulls [sic]”. However, Flanders lamented that he had "sirched Boston and sent to New York but can not find one [sic]". 174 Indeed, as in London, the New York Mechanics' Institute, where Flanders might have practised his reading, did not have a copy. ${ }^{175}$ In writing transnational histories, it is easy to get caught up in a narrative of movement and circulation. As this paper has already shown, managing the transatlantic publication and reception of Crania Americana was by no means straightforward. But Combe's advertisement also invites us to pay greater attention to the absences of movement, the places where Morton's work did not travel. For working-class men like Flanders, Prichard and Watson's jostling at the British Association meeting might have seemed far away.

\footnotetext{
${ }^{172}$ Morton Papers, series ii, vol i, LCP.

${ }^{173}$ The London Mechanics' Institute library (London, 1881).

${ }^{174}$ Flanders to Morton, 3 March 1849, Morton papers, series i, LCP.

${ }^{175}$ Catalogue of the library of the Mechanics' Institute of the city of New-York (New York, 1844).
} 


\section{CONCLUSION}

Crania Americana, despite its title, cannot be read as a straightforward product of antebellum American culture. This paper has shown how actors on both sides of the Atlantic shaped the publication and the reception of Morton's alluring folio volume. What's more, it has also suggested how histories of science and histories of the book may contribute further to one another as we move beyond national studies. In this case, the material world of transatlantic exchange both helped and hindered the efforts of those looking to promote Crania Americana within a range of emerging disciplines. In fact, it was through these debates that anthropology and phrenology came to be thought of as distinct entities. The boundary-work in establishing different scientific disciplines therefore took place over a greater range of geographies than has previously been acknowledged. Particularly for anthropology, there is a need to appreciate the material and intellectual relations between different national traditions. Furthermore, in the case of phrenology, there is a need to consider how the boundaries between science and non-science were also forged within an increasingly globalized world. ${ }^{176}$

Beyond Crania Americana, historians have acknowledged the importance of scientific atlases in the emergence of new disciplines. Lorraine Daston and Peter Galison rightly argue that atlases lay "the visual foundations upon which many observational disciplines rest". Atlases thus "define the working objects of disciplines". Throughout their study, Daston and Galison stress the importance of different modes of image production, from engravings in the eighteenth century to photography in the twentieth. They also chart the relationship between the production of an image and accompanying "epistemic virtues". ${ }^{177}$ But in making this particular connection, Daston and Galison assume that atlases

\footnotetext{
176 "Boundary-work" has most often been considered in much more local settings, see Thomas Gieryn, "Boundary-work and the demarcation of science from non-science: strains and interests in professional ideologies of scientists', American sociological review, xlviii (1983), 781-795.

${ }^{177}$ Daston and Galison, op. cit. (ref. 20), pp. 17-54.
} 
act as relatively straightforward windows onto the intentions of authors. They are also left with little to say about the complex material processes of reproduction and reception uncovered in this study. In fact, Morton's demands as an author were constantly moderated by a range of interested parties, from his publisher in Philadelphia to Prichard in Bristol. Crucially, this was a process which began prior to publication. The sheer heterogeneity of reader responses to Crania Americana also raises serious questions about the utility of charting the emergence of disciplines and epistemic virtues from the perspective of authors alone.

Atlases in fact appear as rather unlikely candidates to structure scientific activity. They are after all expensive to print, cumbersome to move about, difficult to access and often limited to short print runs. These problems are all compounded when we consider reception on an international scale. But despite this, Morton lived through a period which saw the emergence of a range of influential examples, from Murchison's Silurian system (1839) to Thomas Say's American entomology (1824-28). ${ }^{178}$ By studying reviews, extracts and advertisements we can make better sense of the relative success of this format. As a prestigious volume, Crania Americana was reproduced and reinterpreted time and time again, whether as a loose lithograph at the British Association or as a woodcut in the American journal of science. This intense process opened up a space in which different audiences confronted one another and, in doing so, disciplinary categories emerged as a means to promote one reading over another. Despite all the merits of Daston and Galison's work, it is important to recognize that atlases did not shape scientific disciplines in isolation. Rather, they gained disciplinary purchase through the variety of ways in which they were reproduced and read.

\footnotetext{
${ }^{178}$ John Thackray, “R. I. Murchison's Silurian System (1839)", Archives of natural history, ix (1978), 61-73 and Blum, op. cit. (ref. 90), p. 54.
} 
Finally, whilst this paper has concentrated on the detailed transatlantic relationship between British and American protagonists, it also lays the foundation for histories of scientific atlases stretching beyond the Anglo-American world. Throughout the 1840s, Morton continued to promote his work overseas, placing it within an even broader range of institutional and disciplinary settings. In 1843 Morton sent a copy of Crania Americana to the Asiatic Society of Bengal where it was read by British army surgeons returning from the frontier. ${ }^{179}$ By 1844 , the Société Ethnologique in Paris had also obtained a copy. ${ }^{180}$ There it was read by the "father of ethnology in France", William Frederic Edwards, a man Prichard had hoped to emulate through the foundation of the Ethnological Society of London in 1843. ${ }^{181}$ Soon afterwards, the Royal Society of Northern Antiquaries in Copenhagen also received a copy. This group approached Morton's plates within yet another embryonic tradition, that of folkloric studies of the Arctic. ${ }^{182}$ Today, scholars are too quick to situate Morton within histories of anthropology. These examples, along with the more detailed case presented in this paper, illustrate the fallacy of such an approach. By following Crania Americana to Russia, we can get one last look at just how difficult it was for nineteenthcentury readers to pin down Morton's beautiful yet troubling volume. In 1845 Charles Cramer of the Imperial Mineralogical Academy in St Petersburg wrote to Morton complaining of the troubles he had faced in obtaining a copy. Cramer explained how a shipment of boxes, possibly containing Crania Americana, had been sent from New York addressed to the "Theological Institute" in St Petersburg. But no such institution existed. Cramer suggested to Morton that the addressee perhaps meant the "Geological Institute".

\footnotetext{
${ }^{179}$ Asiatic Society of Bengal to Morton, 18 April 1843, APS and Martin to Morton, 30 August 1844, Morton Papers, series i, LCP

${ }^{180}$ Mottelettes to Morton, 9 April 1844, Morton Papers, series i, LCP

${ }^{181}$ Claude Blanckaert, "A Jamaican émigré as the 'father of ethnology in France'”, in George Stocking (ed.), Bones, bodies and behavior: essays in behavioral anthropology (Madison, 1988), 18-55.

${ }^{182}$ Koeppen to Morton, 27 March 1847, Morton Papers, series I, LCP
} 
Still, this institution was distinct from the Imperial Mineralogical Academy at which Cramer worked. By a "slight misnomer of your agents", Crania Americana had been lost amidst the

plethora of expanding scientific institutions in Nicholas I's Imperial Russia. ${ }^{183}$ As Cramer learnt to his cost, what to write on an address label was tantamount to answering how Crania Americana should be read. Theological or phrenological, ethnological or geological? In the nineteenth century, no one was certain.

\section{ACKNOWLEDGEMENTS}

I would like to thank Ann Fabian, Simon Schaffer, Jim Secord, Richard Staley, Alice Poskett and Sadiah Qureshi for their comments on earlier drafts of this paper. I also benefitted from presenting this work on both sides of the Atlantic: at the Cabinet of Natural History at the University of Cambridge and at the History of Medicine Working Group at Harvard University. Finally, I would like to acknowledge the generous financial support of the Philadelphia Area Center for the History of Science, the Francis A. Countway Library, the British Society for the History of Science and Trinity College, University of Cambridge.

${ }^{183}$ Cramer to Morton, 5 August 1848, Morton Papers, series i, LCP. 